NBER WORKING PAPER SERIES

\title{
ELIMINATING THE PASS-THROUGH: TOWARDS FDI STATISTICS THAT BETTER CAPTURE THE FINANCIAL AND ECONOMIC LINKAGES BETWEEN COUNTRIES
}

\author{
Maria Borga \\ Cecilia Caliandro \\ Working Paper 25029 \\ http://www.nber.org/papers/w25029 \\ NATIONAL BUREAU OF ECONOMIC RESEARCH \\ 1050 Massachusetts Avenue \\ Cambridge, MA 02138 \\ September 2018
}

The views expressed in this paper are those of the authors and should not be considered as representing the official views of the OECD, its member countries, or the National Bureau of Economic Research. The authors wish to thank Nadim Ahmad, Caroline Mehigan, Joachim Pohl, Kamran Bilir and participants at the NBER-CRIW Conference on the Challenges of Globalisation in the Measurement of National Accounts, delegates to the OECD Working Group on International Investment Statistics, and colleagues in the OECD Investment Division for valuable comments, and Emilie Kothe and Perla Ibarlucea Flores for their useful statistical assistance.

NBER working papers are circulated for discussion and comment purposes. They have not been peer-reviewed or been subject to the review by the NBER Board of Directors that accompanies official NBER publications.

(C) 2018 by Maria Borga and Cecilia Caliandro. All rights reserved. Short sections of text, not to exceed two paragraphs, may be quoted without explicit permission provided that full credit, including $\odot$ notice, is given to the source. 
Eliminating the Pass-Through: Towards FDI Statistics that Better Capture the Financial and Economic Linkages between Countries

Maria Borga and Cecilia Caliandro

NBER Working Paper No. 25029

September 2018

JEL No. E01,F21,F6

\begin{abstract}
FDI plays a central role in managing global production networks, but FDI statistics also reflect other factors, including tax avoidance, that make it difficult to differentiate between FDI for "long-term" investments that serves as a source of growth and FDI that is purely financial and has little real economic impact as it merely passes through an economy. This latter FDI also obscures the ultimate sources and destinations of FDI. This paper addresses these challenges by developing a framework for consolidated FDI statistics based on the nationality of the MNE group that complements residency-based FDI statistics. While residency-based statistics are useful to identify where financial claims and liabilities are held, nationality-based statistics provide information on who makes the decisions, reaps the benefits, and bears the risk. Consolidated FDI statistics remove pass-through capital and are better for understanding 'real' financial integration between economies and for analysing the relationship between the financing of MNEs and their operations. While some countries produce separate FDI statistics for resident Special Purpose Entities (SPEs) to identify pass-through capital, we demonstrate that this only provides a partial view and that about one-quarter of the inward FDI positions in a selection of European countries reflects pass-through capital through non-SPEs.
\end{abstract}

\author{
Maria Borga \\ OECD \\ rue André Pascal, 75016 Paris \\ FRANCE \\ maria.borga@oecd.org \\ Cecilia Caliandro \\ OECD \\ rue André Pascal, 75016 Paris \\ FRANCE \\ Cecilia.CALIANDRO@ oecd.org
}




\section{Introduction}

Foreign Direct Investment (FDI) has been and remains a key aspect and driver of globalisation. Multinational enterprises (MNEs) access markets and key inputs, such as natural resources and human capital, and locate stages of production in countries to take advantage of factor cost differences through their foreign investments. These foreign investments have facilitated the creation of complex global production chains managed by (MNEs) that support employment and generate income in the host economies. FDI statistics seek to measure these long term investments. However, other factors, in particular fiscal optimisation, have also played a role in the shape and depth of these chains. When the FDI flows are related to purely financial flows engineered to minimise tax payments or overcome regulatory barriers, there is little direct impact on the host economy, at least in a traditional production sense. This latter form of FDI often involves MNEs channelling investments through several countries, 'inflating' FDI flows and positions as each flow into and out of each country is counted even if the capital, or income, is just passing through. This can make it difficult to interpret FDI statistics in the sense that they are not 'real' and provide little in the way of "long-term" investments in the host economy. In essence, the financial structure of the MNE as captured in FDI statistics does not match the operational structure of the MNE, which reflects the organisation of its operations across countries. Indeed, in some countries such as Hungary, so significant is the perceived scale of 'pass-through' capital that the policy focus now looks in large part at net rather than gross flows of FDI to determine the amount of inward FDI that remains in the host economy; however, while this approach provides a better metric for Hungary than traditional FDI statistics, it is far from ideal for countries with significant amounts of outward investment that originate from their economies. Moreover, this approach cannot provide information on the ultimate sources and destinations of FDI when the statistics are compiled by immediate partner country.

The main goal of this paper is to propose a definition of pass-through capital, together with experimental estimates, based on the ultimate ownership and location of the assets that can be used as the basis for techniques to consolidate FDI statistics to remove these 'distortionary' flows, and in turn reallocate FDI positions and income flows from immediate to ultimate partner economies. The statistics, therefore, take a nationality approach to classification by reflecting the entity that ultimately influences or controls the FDI units and, thus, could contribute to further developing nationality-based statistics to better analyse globalisation.

However, this is not the only area where FDI data, on its own, may fail to create a complete picture of the overall scale of the impact of investment within an economy. Because MNEs can leverage their direct investments, parent enterprises can control assets in the host country that are many multiples of their initial investment. As discussed further below, the framework proposed in the paper to consolidate FDI statistics can be extended to capture the full financing of the MNE, providing a more complete picture of the economic involvement of the MNE in the host and home economies. 
The methodology proposed in this paper would produce statistics that are designed to address some important policy issues surrounding FDI. For example, they would provide better measures of financial integration between economies by stripping out the financial intermediation activities within MNEs. The statistics could be linked to other statistics capturing the operations of MNEs to analyse the links between FDI and trade as well as provide information on the alignment between where economic activity occurs and where the MNE attributes its income. Finally, they could provide a more complete picture of the involvement of the MNE in the economy as well as its cross-border and local exposures.

The first section of this paper gives some examples of the ways MNEs pass capital along their ownership structures and establishes the connection between pass-through capital and ultimate partner country. The second section defines what we mean by pass-through capital in terms of direct investment positions. From this, the related definition of pass-through income is derived. Then, the paper defines the concepts of ultimate investing country, based on the nationality of the ultimate investor, and of ultimate host country based, on the objective of producing symmetric statistics. The third section provides experimental estimates for some European members of the OECD to provide order of magnitude estimates of their importance and potential 'distortionary' impact on current FDI statistics. The fourth section considers the relationship of the proposed consolidated FDI statistics to other sets of economic statistics as well as some unresolved issues. The fifth section discusses potential policy uses for the proposed statistics. The final section concludes and provides some recommendations for ways forward.

\section{Pass-through capital: issues and examples}

Interpretability challenges presented by measurement issues with FDI statistics are not new (see Box 1), but the spotlight has intensified in recent years, particularly with regard to pass-through capital. Put simply, pass-through capital is capital that flows into one economy and that is subsequently invested in another economy. In a 2016 report, Blanchard and Acalin concluded that a large proportion of measured FDI flows consisted of flows going into and out of countries on their way to their final destinations (passing through) and moreover that these flows were, in effect, driven by changes in tax regimes and short-run movements in U.S. monetary policy to a much greater extent than would have been expected if the flows were actually in relation to the long run, 'bricks and mortar' type of investment that analysts typically infer from FDI statistics. Lane and Milesi-Ferretti (2017) drew similar conclusions, finding that measured FDI flows inhibited the post-crisis analysis of international financial integration as they show that much of the expansion in FDI flows was with financial centres, suggesting that it was driven by the increasing complexity of corporate structures rather than by 'genuine' FDI flows.

MNEs can access financial systems in many different countries to optimise their capital structures, so there are several different forms that pass-through capital can take. This is, of course, not a new phenomenon, although it is growing, and the latest international standards (BD4) ${ }^{1}$ began to address this issue through the recommendation that entities that have pass-through capital activities as their only, or main, activity and that have little or no physical presence in an economy are separately identified. Excluding FDI associated with these entities, called Special Purpose Entities (SPEs), yields better

\footnotetext{
${ }^{1}$ The OECD's Benchmark Definition of Foreign Direct Investment, $4^{\text {th }}$ edition (BD4) was published in 2008. It provides the most complete and detailed guidance on the coverage, collection, compilation, and dissemination of FDI statistics. In addition to providing guidance on the collection of aggregate FDI statistics that is aligned with the IMF's Balance of Payments and international Investment Positions Manual, $6^{\text {th }}$ edition (BPM6) but also offers guidance on compilation of supplemental FDI series that enhance the usefulness and relevance of FDI statistics.
} 
measures of the inward FDI that is having a real impact on their economy and of the outward FDI that originates in their economy. However, BD4 acknowledged that while SPEs are an important channel for pass-through capital, they are not the only one. As such, it included developing guidance on the identification of capital passing through operating affiliates on its research agenda.

\section{OECD Benchmark Definition of Foreign Direct Investment, 4th edition: Recommendations Related to Pass-through Capital}

The 4th edition of the OECD's Benchmark Definition of Foreign Direct Investment (BD4) took an important step towards improving the measurement of FDI statistics by addressing some of the challenges raised by pass-through capital. BD4 recommended that FDI associated with resident Special Purpose Entities (SPEs) be separately compiled so that FDI statistics excluding resident SPEs could be derived. SPEs are entities whose role is to facilitate the internal financing of the MNE but that have little or no physical presence in an economy. By excluding such entities from their FDI statistics, countries have a better measure of the FDI into their country that is having a 'real' impact on their economy. In addition, BD4 also recommended use of the extended directional principle to better capture the direction and degree of influence of the investment and to remove some double-counting in the FDI statistics when debt passes through affiliated entities, called fellow enterprises (BD4, page 29-31). Under the extended directional principle, if the fellow enterprise in the reporting economy makes a loan to a fellow in another country, it is treated as a reduction in inward investment in the reporting economy if the common direct investor is nonresident because the funds that flowed into the reporting economy from the foreign direct investor have now flowed to another country, reducing the amount of foreign investment in the reporting economy. Previously, such loans were usually treated as outward investment by the resident fellow but should not have been because it is their common direct investor that retains the influence.

Additionally, to look through complex corporate structures to see the ultimate source of investment, BD4 recommended that countries compile inward investment positions according to the Ultimate Investing Country (UIC) to identify the country of the investor that actually controls the investments in their country. Although not directly related to the 'pass-through' problem, the ability to identify FDI flows on a UIC basis can be an important part of a comprehensive solution to the measurement issues in FDI statistics.

Nevertheless, BD4 recognized that these were only partial solutions. As such, it included a Research Agenda that included items related to pass-through capital, including through operating affiliates, and to further develop the presentation by ultimate partner country, especially by ultimate host country (BD4, page 223 to 225).

Fully capturing pass-through capital necessarily requires a basic framework for identifying passthrough capital in all its forms. Evidence from the U.S. Bureau of Economic Analysis on the balance sheets of U.S.-owned affiliates shows that pass-through capital is extensive but also that it varies significantly across different sectors. Figure 1 shows the shares of equity investment in other foreign affiliates in the total non-current assets of U.S.-owned affiliates abroad by major sector of the U.S. parent. This variation indicates that pass-through capital could serve several purposes and provide more benefits to enterprises in some sectors than in others. 
Figure 1: Shares of equity in other foreign affiliates in affiliates' total non current assets by major sector of the parent, 2014

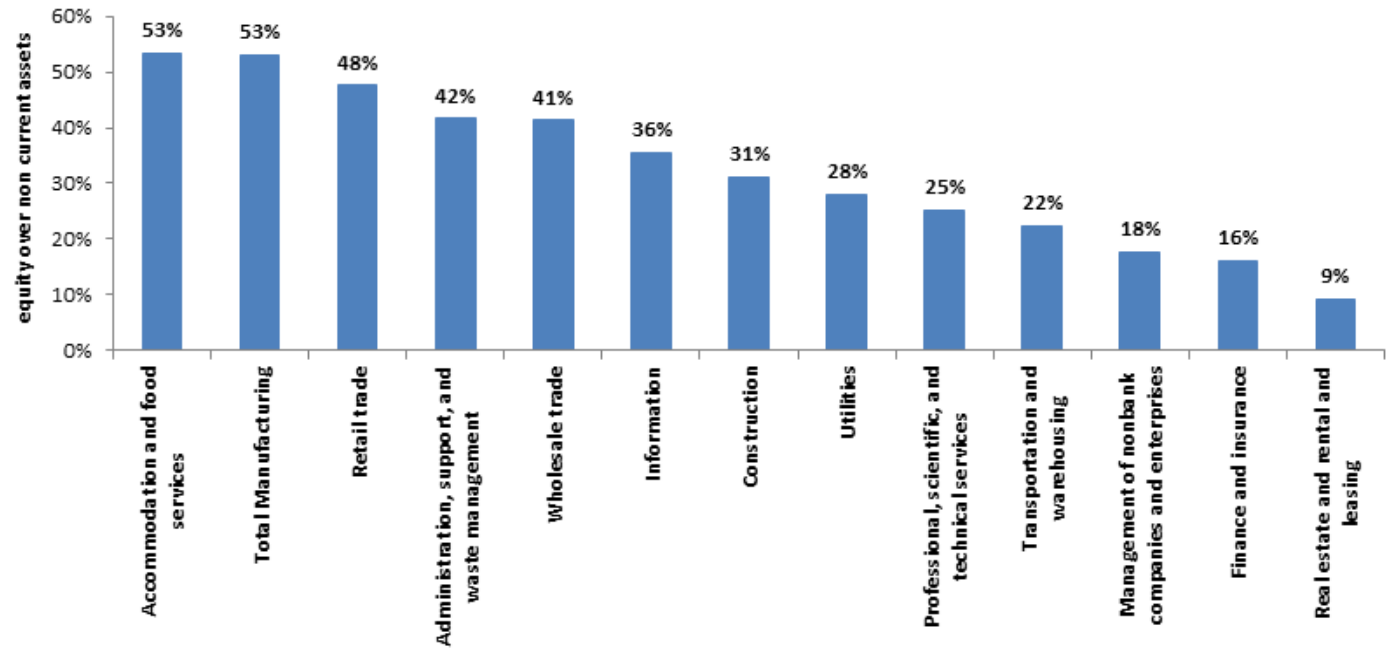

Source: U.S. Bureau of Economic Analysis

Note: Not all sectors could be shown due to data confidentiality.

The discussion below begins to develop a framework through a taxonomy of the motivations for passthrough capital, the characteristics of the countries that attract that type of pass-through, and the likely impacts on the host economy. The taxonomy illustrates the particular difficulties in identifying capital passing though operating affiliates: while the issue of pass-through capital focuses on the distortions between the financial and operational structures of MNEs caused by the fiscal and financial optimisation activities within the firm, some forms of pass-through capital in operating affiliates facilitate the operational structure, making it difficult to distinguish the pass-through capital. At the highest level, the framework divides pass-through activities into those that occur completely within the firm and so only involve FDI and those that involve financing from sources other than FDI; this latter type would have to extend the identification of pass-through capital to other forms of international investment, such as portfolio and other investment, to fully address them in the International Investment Position (IIP) statistics. Much of this discussion draws on Lewellen and Robinson (2013).

\subsection{Pass-through capital within the firm}

Pass-through capital within the firm can take different forms and serve different purposes. Five major reasons for pass-through capital are discussed below.

1) Tax avoidance. This is probably the most cited motivation for pass-through capital. MNEs can channel funds through affiliates in different countries to both shift income as well as take advantage of opportunities to defer taxes on income (see Desai, Foley, and Hines (2003) for a discussion of the use of indirect ownership to avoid and defer taxes). This activity can be done through both SPEs and operating affiliates. Somewhat paradoxically, recent initiatives to encourage MNEs to better align where they report income with where they have economic activities ${ }^{2}$ may have exacerbated measurement challenges by encouraging firms to record pass-through capital in affiliates with a small, but real, presence in the host economy (IMF, 2017 Task Force on SPEs report). The capital passing through these 'near SPEs' is not captured in the current statistics of resident SPEs because these entities

\footnotetext{
${ }^{2}$ Such as the G20/OECD framework to address Base Erosion and Profit Shifting (BEPS).
} 
do not meet all of the criteria, especially little or no employment or physical presence in the host economy.

Pass-through capital due to tax avoidance would be associated with countries that offered tax advantages, including special tax treatments for intellectual property (IP). These countries typically offer not only low tax rates but also networks of double taxation treaties. Pass-through capital associated with tax avoidance is likely to result in significant FDI positions for the countries involved but have less direct impact on the economy (that is, lower levels of employment, value added, and tangible capital at the foreign-owned entities). This type of pass-through capital would be characterised by high asset to employment ratios as well as significant royalty and license fee income at the entity involved in the pass-through. It could also be associated with certain industries, such as holding companies. While it might not have significant direct impacts, it can have considerable indirect impacts on the host economy by supporting industries offering services to foreign investors such as financial services and tax planning industries; these indirect impacts can be particularly important in small economies.

2) Expropriation or other risks to the value of their investment. MNEs that seek to limit their exposure to "political" risk or wish to benefit from an advantageous investor protection regime could structure an investment through a country that offers the desired treaty-based protections. For example, if the investor's home country does not have a bilateral investment treaty or equivalent arrangement with the host country, it may choose to hold the investment indirectly through one of its affiliates in a country that does have such a treaty with the host country of the investment. An examination of disputes records and law firms' client advisory services shows that, for example, subsidiaries in the Netherlands are often recommended and used by investors that are ultimately controlled by non-Dutch parents to bring claims under Dutch IIAs (Van Os and Knotterus, 2011). ${ }^{3}$ Because treaties are often interpreted as to enable indirect shareholders to obtain compensation for losses, in the event that host government measures affect the operating company (if there is a treaty in force between their country of nationality and the host country), complex ownership structures may actually be advantageous because they offer options for additional shareholder claims (Gaukrodger, 2013). ${ }^{4}$ As a result, this type of pass-through capital would be more likely to occur in host countries with a large network of bilateral investment treaties or in countries that have treaties with unusual partners. It would also likely have limited direct impacts on the host economy but possibly could have indirect impacts by supporting an industry offering services to foreign investors.

3) Reduction in transaction costs. Affiliates in the MNE's production network that have a significant amount of interactions may find closer ownership links reduce transaction costs and facilitate these interactions. For example, an MNE investing in the United States may invest in Mexico and Canada through their U.S. operation, forming an integrated, regional operation. While the motivation for this pass-through capital clearly differs from those described above, it remains the case that the U.S. operation is still facilitating pass-through capital for the ultimate parent.

This type of arrangement would be more likely to happen between affiliates with strong commercial links or with more complex production processes and products, where the transaction costs would be expected to be higher. Thus, it is more likely to happen between affiliates in countries that share strong

\footnotetext{
${ }^{3}$ Of the 41 claims that had been brought under Dutch IIAs and were known as of June 2011, in 29 of them, the ultimate controlling parent was not Dutch, and 25 of the claimants had no staff in the Netherlands.

${ }^{4}$ For a review of the role that complex ownership structures can play in obtaining investor protections, see Pohl (2018).
} 
commercial ties as evidenced by significant trade flows and that share preferential trade agreements. It would also be more common in countries that are physically or culturally close.

With this type of pass-through capital, the financial structure overlaps with the reporting and operational structure within the MNE. As such, there is likely to be more direct impacts in the host economy as these pass-through entities may have significant employment, value added, $R \& D$, and trade in both goods and services; they are also likely to have indirect impacts in the host economy in a number of areas, including by integrating domestic suppliers into the production networks they coordinate.

4) Inherited ownership links. When an MNE acquires an existing MNE, it also acquires the ownership structure. In these cases, the amount paid by the acquiring MNE covers not just the assets in the reporting economy where the acquired MNE was headquartered, but also assets in other economies where the acquired MNE's foreign affiliates were located; there will not be any FDI transactions recorded in the countries of these foreign affiliates since they were already foreign-owned. The acquiring MNE may choose not to change the ownership structure, in which case the acquisition creates an ownership chain and the position in the reporting economy reflects not just the value of the assets held in that economy but also the assets in the subsequent economies along the chain. In this form of pass-through capital, the financial structure and operational structure could overlap, and, so, as for the case of the reduction in transaction costs discussed above, the motivation may not represent what is usually associated with pass-through capital but, nevertheless, the acquired MNE is now serving as a pass-through entity for its new parent. ${ }^{5}$

This form of pass through would be more likely to occur in countries where more of the inward FDI transactions were the result of M\&A than of greenfield investment and, more specifically, that are home to MNEs that have since been acquired. It is hard to assess the impacts of this type of pass-through capital on the host economy. While it may be expected that there would be a drop in employment and value added at the former head of the MNE, it may still maintain significant operations there.

5) Protection of the parent from claims against the affiliate. If the parent is concerned that the affiliate is exposing them to financial claims, they may be more likely to own it indirectly to limit those claims. This might be the case, for example, with joint ventures or other cases of shared ownership. This might be more likely to happen in host countries that provide greater protections to investors as discussed above. It is hard to assess the impacts of this type of pass-through capital on the host economy. On the one hand, it might be more associated with indirect impacts in the host economy if it is driven by investor protection, but, on the other hand, enterprises that are joint ventures or in which the foreign investor holds a minority stake could have significant employment, value added and so on.

\subsection{Pass-through capital outside of the firm}

1) External financing. MNEs can raise financing outside of the firm and may do this through their foreign affiliates. For example, MNEs can use their foreign affiliates to raise capital by issuing debt securities and then channel the funds raised to other parts of the MNE, including back to the parent. The first part of this transaction is either domestic or portfolio investment, but the second part is an FDI transaction. There is evidence that this activity is increasing, particularly for MNEs from emerging

\footnotetext{
${ }^{5}$ The acquiring MNE could choose to change the ownership structure and hold these foreign affiliates directly, in which case the FDI positions would be reclassified from the economy of the former parent to the economies of the foreign affiliates. In this case, there would be no pass-through capital and the FDI statistics would accurately reflect both the value and ultimate origin and destinations of the FDI.
} 
market economies (Tarashev et al, 2016) and that it is tied to the presence of capital controls (Caballero et al, 2015). ${ }^{6}$ In this case, pass-through capital goes beyond FDI to include the other functional categories of international investment, and, so, the concept of pass-through capital would need to be broadened beyond FDI to address it.

This form of pass-through capital would be more likely in countries with deep capital markets, strong investor protections, and offering sophisticated financial services. It would not have significant direct impacts in the economy but could have significant indirect impacts in the financial services sector.

2) Financial conduits. A private investor may establish an affiliate in a foreign country for the purpose of engaging in portfolio investment from the host economy. It is the first leg of this case that brings the transaction within the scope of FDI, while the other leg would either be in domestic investment or in the other functional categories of international investment. This kind of pass-through capital would be more likely in countries that offer offshore or sophisticated financial services or secrecy. The home country would likely be one with higher tax rates and that had stronger controls on outflows of portfolio capital than on direct investment. It would not have significant direct impacts in the host economy but could have significant indirect impacts in the financial services sector.

3) Corporate redomiciliations. In a corporate redomiciliation, the headquarters of the company moves to another country. While they can take many forms, corporate redomiciliations often involve substantial FDI flows that are almost completely, if not completely offset, by portfolio investment flows. It is possible that these kinds of transactions, when they result in offsetting flows, could be treated as a form of pass-through capital because the capital that has flown into the reporting economy flows out to other economies. In this case, the characteristics that would make a country likely to host a redomiciliation would be those offering relative tax, regulatory, and other benefits to foreign investors. The extent of impacts on the host economy would depend on the extent to which the redomiciled company actually shifted operations to its new headquarters country.

\section{Defining pass-through capital and the ultimate partner country}

The section begins with the definition of pass-through capital and ultimate partner country in FDI positions. It then examines how these concepts could be extended to FDI income. Next, it discusses implications for measuring pass-through capital in financial flows and for producing these statistics.

\subsection{Pass-through capital in FDI positions}

This section begins with the definition of pass-through capital in FDI positions illustrated by two examples. It, then, discusses the conventions applied in these examples, and, next, it presents a nationality-based consolidation that captures the entire financing of the MNE.

\subsubsection{Pass-through capital and ultimate partner country}

The concept of pass-through capital is straightforward: capital flowing into the host economy that is then invested in a subsequent economy. However, identifying these flows in practice is more complicated. Entities receive financing from a variety of sources and use it in a variety of ways, especially operating affiliates, which can blur the relationship between inward and outward flows. As

\footnotetext{
${ }^{6}$ Going further, Shin and Zhou (2013) find evidence of non-financial MNEs issuing liabilities in some countries and currencies at the same time they acquire assets in other countries and currencies to generate profits.
} 
a result, assumptions, necessarily, have to be made about the relationship between the financing and its eventual use. ${ }^{7}$

The definition in this paper is derived from the position data and is based on the concept of ultimate ownership of the FDI assets. In FDI statistics, the inward position in a country reflects not just the claims on the direct investment enterprise in that country but may also reflect foreign direct investments that enterprise may have. This necessarily means that the outward investment position of a country reflects investments made by entities headquartered in that country but also by enterprises that are ultimately owned by investors in another country. Therefore, any reasonable definition of the UHC would have to, in effect, remove the multiple-counting that results from pass-through capital (Mahoney, 2007). The removal of pass-through capital also has implications for statistics by UIC because, ideally, statistics by UIC and UHC would be symmetric. Indeed, eliminating multiple-counting of pass-through capital in constructing UIC statistics is preferable from a policy perspective as the ultimate goal of the statistics is to identify the country of the investor influencing the investment in the host country. However, as before, that influence is overstated if part of that investment is capital passing through the host economy. In other words, the two ideas-pass-through capital and ultimate partner economy-are ultimately and inextricably linked and should be considered together in order to produce complementary FDI statistics that are more analytically meaningful.

Figure 2 below illustrates some of the challenges presented by pass-through capital in current FDI statistics compilation, and how interpretability could be improved using the concept of UIC. It presents the ownership diagram of a simple MNE structure consisting of five different enterprises in four different economies; A (in Economy 1, the UIC) is the ultimate controlling parent (UCP), and it owns $\mathrm{B}$ and $\mathrm{C}$ directly and $\mathrm{D}$ and $\mathrm{E}$ indirectly. For each entity and country, the figure shows an abridged balance sheet consisting of total assets, with the equity investments in foreign affiliates broken out; total liabilities; and owners' equity. The figure also shows the ownership chains and the percentage of ownership.

Table 1 shows the inward and outward FDI positions that would be recorded under the extended directional principle. Outward positions are allocated to the immediate partner country, but inward positions are recorded on both the immediate country and UIC basis as recommended in BD4. ${ }^{8}$

Table 1 shows that the inward and outward positions are globally additive, each summing to 340 . But the reallocation of inward positions to economy 1, (the UIC), results in a total of 340 being recorded by economies 2, 3, and 4 as inward investment from economy 1, exceeding 1's total outward FDI of 250 due to pass-through capital. Moreover, under the extended directional principle, the loan between fellow enterprises $\mathrm{B}$ and $\mathrm{C}$ is treated as a reduction in inward investment in $\mathrm{B}$ as the funds that flowed into economy 2 from the fellow enterprises' common direct investor (enterprise A) have flowed to another country (economy 3). This loan does not give B any influence over the operations of C, and, so, should not be recorded as an outward investment. However, because it is recorded against the

\footnotetext{
${ }^{7}$ As a result of these difficulties, BD4 chose to identify entities associated with pass-through capital rather than to identify the flows themselves because it was thought to be more feasible. The criteria listed in BD4 to identify SPEs-including little or no physical presence, foreign ownership, and almost all assets and liabilities of the enterprise represent investments in or from other countries-were designed to identify entities for which almost all of the FDI into and out of SPEs qualified as pass-through capital.

${ }^{8} \mathrm{BD} 4$ recommends that the UIC be identified by proceeding up the ownership chain of the immediate direct investor until a unit that is not controlled by any other unit is reached.
} 
immediate partner economy, it does lead to an asymmetry in the bilateral inward and outward FDI positions reported by the two countries.

Figure 2: Pass-through Capital in a Simple Example of an MNE Ownership Structure

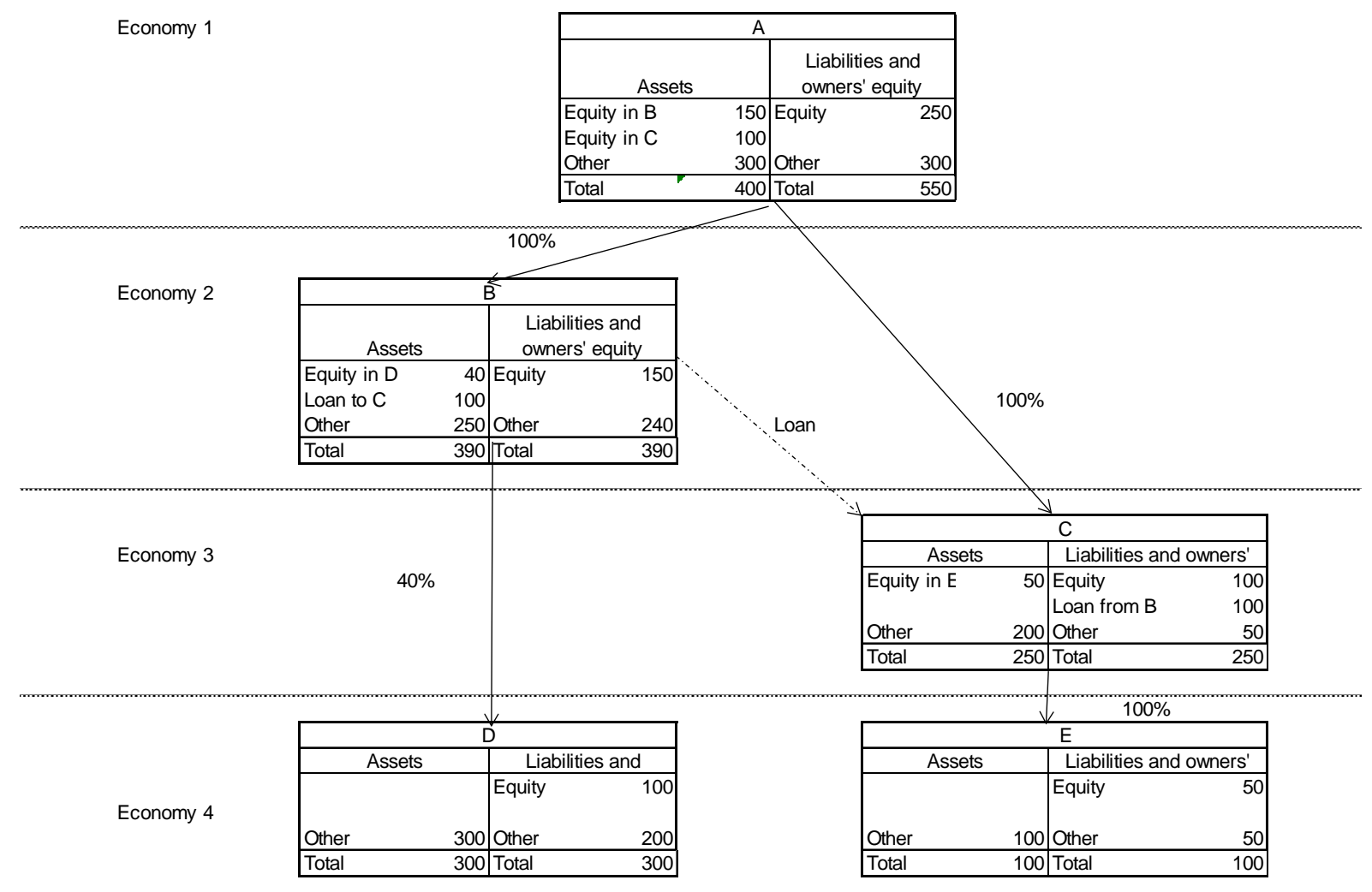

Table 2 presents the results for the consolidated FDI statistics in which pass-through capital has been netted out and positions reallocated to ultimate partner country.

Table 1: Inward and Outward FDI Positions under the Extended Directional Principle

\begin{tabular}{|c|c|c|c|c|c|c|c|c|c|c|c|c|}
\hline \multirow{4}{*}{$\begin{array}{l}\text { Partner } \\
\text { country }\end{array}$} & \multicolumn{12}{|c|}{ Reporting Economy } \\
\hline & \multicolumn{3}{|c|}{ Economy 1} & \multicolumn{3}{|c|}{ Economy 2} & \multicolumn{3}{|c|}{ Economy 3} & \multicolumn{3}{|c|}{ Economy 4} \\
\hline & \multirow{2}{*}{\multicolumn{2}{|c|}{$\frac{\text { Outward }}{\text { Immediate }}$}} & Inward & Outwa & \multicolumn{2}{|c|}{ Inward } & Outw & \multicolumn{2}{|c|}{ Inward } & Outwa & \multicolumn{2}{|c|}{ Inward } \\
\hline & & & $\mathrm{UIC}$ & & & UIC & & & UIC & & & UIC \\
\hline 1 & 0 & 0 & 0 & 0 & 150 & 50 & 0 & 100 & 200 & 0 & 0 & 90 \\
\hline 2 & 150 & 0 & 0 & 0 & 0 & 0 & 0 & 100 & 0 & 0 & 40 & 0 \\
\hline 3 & 100 & 0 & 0 & 0 & -100 & 0 & 0 & 0 & 0 & 0 & 50 & 0 \\
\hline 4 & 0 & 0 & 0 & 40 & 0 & 0 & 50 & 0 & 0 & 0 & 0 & 0 \\
\hline Total & 250 & 0 & 0 & 40 & 50 & 50 & 50 & 200 & 200 & 0 & 90 & 90 \\
\hline
\end{tabular}

If the positions were also reallocated to the ultimate investing country, then economy 1 would still report outward investment of 250 but, now, Economy 2 would recognise that both the loan of 100 to C and the equity investment in D of 40 are pass-through capital and would net these from its inward and outward investment and the remaining inward investment would remain allocated to economy 1 , the economy of the ultimate investor A. Economy 3 would also recognise that the equity investment of 50 in $\mathrm{E}$ is pass-through capital and net it from its inward and outward investment and the remaining inward 
investment would be reallocated to economy 1. Economy 4 does not have pass-through capital and would reallocate its inward position to economy 1 . In this case, the only country with outward investment is economy 1 since that is the economy of the domestic parent of the MNE; economies 2 and 3 no longer have outward investment since all of their outward investment was from A, the foreign and ultimate controlling parent. As before, the statistics are globally additive but now the amount of inward FDI attributed to Economy 1 (the UIC) is the same as its outward investment (250), reflecting the elimination of pass-through capital.

Table 2: Inward and Outward Positions under Consolidated FDI Statistics by Ultimate Partner Country

\begin{tabular}{|l|c|c|c|c|c|c|c|c|}
\hline \multirow{3}{*}{$\begin{array}{l}\text { Partner } \\
\text { country }\end{array}$} & \multicolumn{9}{|c|}{ Reporting Economy } \\
\cline { 2 - 9 } & \multicolumn{2}{|c|}{ Economy 1 } & \multicolumn{2}{c|}{ Economy 2 } & \multicolumn{2}{c|}{ Economy 3 } & \multicolumn{2}{c|}{ Economy 4 } \\
\hline & Outward & Inward & Outward & Inward & Outward & Inward & Outward & Inward \\
\hline 1 & 0 & 0 & 0 & 10 & 0 & 150 & 0 & 90 \\
\hline 2 & 10 & 0 & 0 & 0 & 0 & 0 & 0 & 0 \\
\hline 3 & 150 & 0 & 0 & 0 & 0 & 0 & 0 & 0 \\
\hline 4 & 90 & 0 & 0 & 0 & 0 & 0 & 0 & 0 \\
\hline \hline Total & 250 & 0 & 0 & 10 & 0 & 150 & 0 & 90 \\
\hline
\end{tabular}

While BD4 recommended a supplemental presentation of inward FDI positions by UIC, it also included an item on the BD4 Research Agenda to develop a presentation by ultimate host country (UHC) as the natural counterpart of the presentation by UIC. If we define the UHC as the country where the foreignowned assets are ultimately located and that the reallocation to UHC should be based on the total intragroup funding that each foreign affiliate receives net of any intragroup funding it provides to fellow enterprises or its subsidiaries, then the FDI positions by UHC can be derived from the inward statistics by using mirror relationships.

Of course, ownership structures can be more complicated than presented in Figure 2. The first complication is that FDI statistics cover influence as well as control relationships and, so, can include multiple direct investors. The second difficulty is that FDI positions can be negative. Negative positions usually result when the loans from the affiliate to its foreign parent group exceed the loans and equity capital it has received. ${ }^{9}$ The final difficulty is that MNEs can raise financing from outside of the group. Figure 3 presents a more complicated ownership structure including these aspects. Each case will be discussed more completely below as well as the measurement and identification challenges that they raise.

In figure 3, there are 2 direct investors in enterprise $\mathrm{E}$ in economy 4, both from economy 3 . Under the recommendations in BD4 for the UIC, the $20 \%$ of equity held by enterprise $\mathrm{Z}$ would be attributed to Economy 3 , while the equity investment held by $\mathrm{C}$ would be reallocated to country 1 as would the loan from enterprise B in economy 2. An alternative way to reallocate the FDI positions to the UIC is based on who controls the enterprise rather than who owns the investment. The implications for this

\footnotetext{
${ }^{9}$ Negative positions could also occur if the distributed earnings exceeded total earnings or the affiliate operated at a loss, resulting in negative reinvested earnings.
} 
Figure 3: MNE Ownership Structure

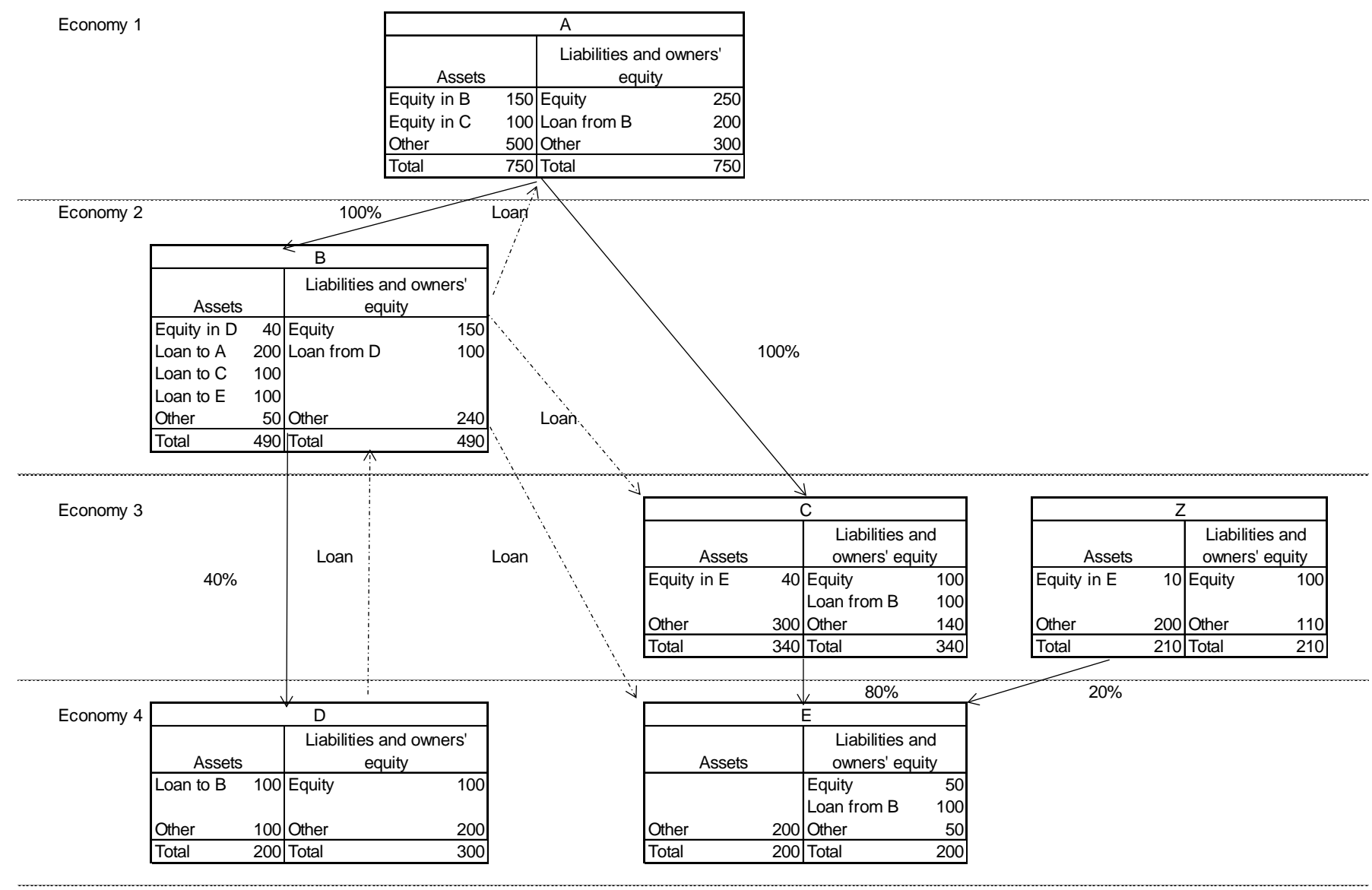


change in identifying the Ultimate Investor will be discussed below. Enterprise B in economy 2 has a minority ownership interest in enterprise D in economy 4, but, in this case, it is assumed that no other investor owns more than $10 \%$ of the voting power, so there are no other direct investors. Enterprise B plays an important role in the MNE's financing structure, borrowing money from some parts of the MNE as well as from outside of the group and lending money to other parts of the MNE.

Table 3 presents the standard FDI statistics in the upper panel that would result from this ownership structure, and there is a negative inward position in economy 2 from economies 1 , 3, and 4 under the extended directional principle resulting from the role that enterprise B plays in the internal financing of the MNE. So under what circumstances does pass-through capital occur in the case of negative positions? There are three possible cases to consider. First, if the inward position of enterprise B is negative and its outward position is negative, then there has been pass-through capital, but it has gone in the opposite direction. This is the case shown in figure 3; in this case, enterprise B has borrowed more from its affiliate (enterprise D) than it invested and some of this financing contributes to the financing that it provides to other parts of the MNE, including the parent. In the other two cases, there is no pass-through capital. If the inward position in enterprise B is negative but its outward position is positive, then the financing for the outward investment must have come from extra-group sources. This would be the case, for example, if there had been no loan from enterprise D to B in figure 3. Similarly, if the inward position in enterprise B had been positive but its outward position in D is negative, then there has been no pass-through capital; in this case, the funding received by B from its parent has not gone to its subsidiary, enterprise D.

To formalise, the amount of pass-through funding, PT, for each enterprise $j$ in period $t$, is:

$$
\begin{aligned}
\mathrm{PT}_{\mathrm{j}, \mathrm{t}} & =\min \left(\mathrm{I}_{\mathrm{j}, \mathrm{t}}, \mathrm{O}_{\mathrm{j}, \mathrm{t}}\right) \text { if the } \mathrm{I}_{\mathrm{j}, \mathrm{t}} \geq 0 \text { and } \mathrm{O}_{\mathrm{j}, \mathrm{t}} \geq 0 \\
& =\max \left(\mathrm{I}_{\mathrm{j}, \mathrm{t}}, \mathrm{O}_{\mathrm{j}, \mathrm{t}}\right) \text { if the } \mathrm{I}_{\mathrm{j}, \mathrm{t}}<0 \text { and } \mathrm{O}_{\mathrm{j}, \mathrm{t}}<0 \\
& =0 \text {, otherwise }
\end{aligned}
$$

Where $\mathrm{I}_{\mathrm{j}, \mathrm{t}}$ and $\mathrm{O}_{\mathrm{j}, \mathrm{t}}$ represent the inward and outward positions of the direct investment enterprise $\mathrm{j}$ in period t, respectively. Looking from the inward FDI perspective, a foreign-owned enterprise with no subsidiaries would have no pass-through capital $\left(\mathrm{O}_{\mathrm{j}, \mathrm{t}}=0\right.$ under (1)). If it did have a foreign subsidiary, the amount of pass-through capital is the smaller of the inward and outward positions of the foreignowned enterprise if both its positions are positive (under (1)) or negative (under (2)), and it is zero otherwise. Looking from the outward FDI perspective, the same amount of pass-through would be identified for direct investors in the economy. The total pass-through capital in the economy would be found by either summing the pass-through capital across the direct investment enterprises or across the direct investors in the economy. This follows one of the methods described in Leino and Yrrko (2014).

The bottom panel of table 3 shows the consolidated FDI statistics that would result from applying this definition and reallocating positions to the ultimate partner country. Starting with economy 4, the inward positions from B in economy 2 (the -60 in D resulting by netting the loan of 100 from the equity investment of 40 plus the loan of 100 to $E$ ) and from C in economy 3 (equity investment of 40) are reallocated to $\mathrm{A}$ in economy 1 , but the investment from $\mathrm{Z}$ in economy 3 remains allocated to economy 3 because $\mathrm{Z}$ is not controlled by another entity. For economy 3 , the pass-through capital from $\mathrm{C}$ to $\mathrm{E}$ is deducted from its inward investment from A (100-40) and, along with the loan from B (100), is reallocated to $A$; the outward investment from $Z$ to $E$ (10) remains as outward investment from economy 3 to economy 4 . For economy 2, the negative outward investment to $D(-60)$ is identified as pass-through capital and is netted from the inward positions from A, C, and E (-250), for a total inward position of 190 allocated to A. For economy 1, there is no inward investment, but its outward investment identifies 
the ultimate destination for its direct investment as well as the fact that enterprise A controls B and uses it as a source of funding to the rest of the MNE.

Table 3: Standard and Consolidated FDI Positions from Figure 2

\begin{tabular}{|l|c|c|c|c|c|c|c|c|}
\hline $\begin{array}{l}\text { Partner } \\
\text { country }\end{array}$ & \multicolumn{9}{|c|}{ Reporting economy } \\
\hline & \multicolumn{2}{|c|}{1} & \multicolumn{2}{|c|}{2} & \multicolumn{2}{|c|}{3} & \multicolumn{2}{|c|}{4} \\
\hline & Inward & Outward & Inward & Outward & Inward & Outward & Inward & Outward \\
\hline 1 & 0 & 0 & -50 & 0 & 100 & 0 & 0 & 0 \\
\hline 2 & 0 & -50 & 0 & 0 & 100 & 0 & 40 & 0 \\
\hline 3 & 0 & 100 & -100 & 0 & 0 & 0 & 50 & 0 \\
\hline 4 & 0 & 0 & -100 & -60 & 0 & 50 & 0 & 0 \\
\hline Total & 0 & 50 & -250 & -60 & 200 & 50 & 90 & 0 \\
\hline \multicolumn{7}{|c|}{ Consolidated FDI Statistics } \\
\hline 1 & 0 & 0 & -190 & 0 & 160 & 0 & 80 & 0 \\
\hline 2 & 0 & -190 & 0 & 0 & 0 & 0 & 0 & 0 \\
\hline 3 & 0 & 160 & 0 & 0 & 0 & 0 & 10 & 0 \\
\hline 4 & 0 & 80 & 0 & 0 & 0 & 10 & 0 & 0 \\
\hline Total & 0 & 50 & -190 & 0 & 160 & 0 & 90 & 0 \\
\hline
\end{tabular}

Another complication arises if the MNE raises financing from outside of the group. This could include any minority ownership interests from the reporting economy, as depicted by enterprise $\mathrm{Z}$ in economy 3 , and funds raised from third parties that are then lent to other parts of the MNE group, as depicted in the case of enterprise B.

\subsubsection{Conventions in the Recording}

There are conventions used in the method discussed above to compile the consolidated FDI positions. Enterprises can receive financing from a number of different sources and can use that financing in a number of different ways. Due to the fungible nature of capital, it is not possible to trace the source to the use. As a result, it is necessary to make assumptions about how much of the FDI received by the enterprise is used in local production and how much passes through. This is much more difficult for operating affiliates than for SPEs.

Some proposed definitions have focused on applying shares of intragroup financing in total financing. For example, one proposed definition of pass-through capital in Mahoney (2007) used the proportion of the total liabilities (including shareholder's equity) of an enterprise that are equity liabilities to a direct investor to determine the amount of its equity assets that should be deemed pass-through capital; so, if one-third of the total liabilities of the enterprise were equity liabilities to its direct investor, then one third of its direct investment equity assets were deemed to be pass-through capital. Other definitions have included debt liabilities as well as equity (OECD, 2006). The assumption in these definitions is that all sources of funding are used equally in all uses. In contrast, the assumption used in this paper is that the intra-group financing is the primary source of funding for intra-group investments.

It is important to note that whichever of the estimation approaches used requires the use of conventions. The preference for the approach (and underlying assumption) used in this paper largely reflects practical reasons. First, it requires less information than those approaches that require information on the full funding of the enterprise. Economies with entities lower in the chain would only need to know details on the ownership shares and investments to and from the entities in their economy; only the country of the UCP would need to have information on the complete chain. Second, basing the amount of passthrough capital on the share of total financing could result in volatility as the share changes due to 
increases or decreases in the amount of total financing needed by the enterprise but with no change in the underlying intrafirm financing. Potentially introducing such volatility in measured FDI is arguably contrary to the goal of measuring stable, long-term financing. Finally, it is in keeping with the extended directional principle in which the full amount of the loan between fellow enterprises is netted from the inward investment of fellows making the loan. The result of the assumption that intragroup financing is the primary source of funding for intragroup investments is that more of the direct investment positions are reallocated to the entities at the end of the chain compared to the assumption that all sources of funding contribute to the intragroup lending.

The second convention that has been used is that the reallocation to the UIC is based on the country of the entity that controls the immediate direct investor; alternatively, it could be based on who controls the direct investment enterprise. When moving to focusing on control of the direct investment enterprises, it makes sense to move to examining only control relationships in the consolidation of the financing structure of the MNE; that is, the definition of FDI covering both influence and control relationships would need to be changed to only control relationships. Table 4 presents the results of the consolidated FDI statistics with only control relationships.

Table 4: Consolidated FDI Positions from Figure 2: Only Control Relationships

\begin{tabular}{|l|c|c|c|c|c|c|c|c|}
\hline $\begin{array}{l}\text { Partner } \\
\text { country }\end{array}$ & \multicolumn{9}{|c|}{ Reporting economy } \\
\hline & \multicolumn{2}{|c|}{1} & \multicolumn{2}{|c|}{2} & \multicolumn{2}{|c|}{3} & \multicolumn{2}{c|}{4} \\
\hline & Inward & Outward & Inward & Outward & Inward & Outward & Inward & Outward \\
\hline 1 & 0 & 0 & -250 & 0 & 160 & 0 & 140 & 0 \\
\hline 2 & 0 & -250 & 0 & 0 & 0 & 0 & 0 & 0 \\
\hline 3 & 0 & 160 & 0 & 0 & 0 & 0 & 0 & 0 \\
\hline 4 & 0 & 140 & 0 & 0 & 0 & 0 & 0 & 0 \\
\hline Total & 0 & 50 & -250 & 0 & 160 & 0 & 140 & 0 \\
\hline
\end{tabular}

One change is that the investment from $\mathrm{Z}$ in economy 3 to $\mathrm{E}$ in economy 4 is no longer shown because it is not a control relationship. Similarly, the investment by B in economy 2 in D in economy 4 nor the loan from $\mathrm{D}$ to $\mathrm{B}$ are included since it is not a control relationship. One thing this highlights is the tradeoff in focusing only on control of the enterprise-the information on minority investors is no longer captured in the data.

\subsubsection{Expanding Consolidated FDI Statistics to Capture the Full Financing of the MNE}

It is instructive to note that consolidated FDI statistics by UIC fits in with the broader thrust towards, and greater interest in, the use of nationality based statistics for understanding globalisation across a number of statistical areas, such as recommendations included in the G20 Data Gaps Initiative for more nationality-based statistics to better understand financial integration and monitor financial stability (Bank for International Settlements, 2015 and Tissot, 2016). In addition a full nationality-based approach could allow the statistics to be expanded to capture other sources of financing to better represent the full economic involvement of the foreign investor in the host economy. Indeed, the framework for consolidated FDI statistics discussed here can be extended to the total assets and liabilities of the MNE. This expansion goes beyond FDI statistics by capturing the cross-border assets and liabilities from other functional categories, especially portfolio and other investments, but also beyond the international accounts by capturing domestic assets and liabilities. Nevertheless, it can be underpinned by the Framework for Direct Investment Relationships (FDIR) to identify the relevant units to be consolidated as well as the ultimate investor. 
The expansion would reveal the extent to which MNEs have leveraged their direct investment to control more assets in the host economy. The difference between the direct investment figures (positions) and the actual value of assets the foreign parent firm controls in the host economy can measure the extent of this leverage. The framework can also be harmonised with the concepts underlying the Activities (AMNE) or Foreign AffiliaTe Statistics (FATS) so that the two data sets can be linked to analyse the relationship between the operations of MNEs and their financing. These statistics could also be linked to datasets developed to explore the competitiveness of economies by allocating value added not by location but instead by ownership of the firms and of the factors involved in production (Federico, 2015). Such a linking would shed light on the role that FDI plays in the competitiveness of economies.

The Working Group on International Investment Statistics (WGIIS) developed a framework for harmonising the concepts and definitions used in FDI and FATS statistics as well as to capture the full financing of the MNE. Called the MNE Framework, it focuses on control relationships and uses rules like the consolidation rules used in international accounting standards to identify intragroup assets. The MNE Framework recommended expanding the coverage of financial variables to total assets and liabilities. So, these statistics would include FDI but would go beyond it to include purely domestic sources of financing and cross-border sources other than FDI. This expansion recognizes that all of the funding received by the enterprise, not just FDI, affects its operations.

Next, the MNE framework made use of the Ultimate Controlling Parent (UCP) concept from the FDIR to classify investment and to define the entities to be covered. The UCP is the entity on top of the ownership chain and which is not controlled by another entity. For inward investment, the MNE framework recommended allocating all variables to the country of the UCP. Not only does this align with the recommendation for a supplemental presentation of FDI statistics by UIC, but it also aligns with the recommendations for compiling AMNE/FATS statistics. For outward investment, it recommends that the entities covered include only non-resident subsidiaries that are controlled by UCPs resident in the reporting economy. That is, it removes from the outward investment of a country investments made by entities that are resident in the economy and that are in turn themselves foreigncontrolled. This prevents overestimation of the amount of overseas assets under control.

Finally, the MNE framework recommended that the financial measures be consolidated for the group to eliminate the double-counting of funds in transit or round-tripping. This consolidation is done by netting investments between the affiliates of the group from the group's total assets and is equivalent to the methods discussed above. This consolidation not only removes fund that go into and out of subsidiaries simultaneously (funds-in-transit) but also removes funds that have been invested by subsidiaries in other affiliated enterprises on behalf of the UCP; the funds removed corresponds to the definition of pass-through capital proposed in this paper. For a complete description of the method, see OECD (2011) and OECD (2015).

The results of expanding the presentation to the full financing of the MNE are presented in Table 5. Table 5 presents the assets that enterprise A controls in each economy. The amount of total assets in column 1 overstates the total assets controlled by A due to intragroup positions, so column (2) identifies the amount of intragroup assets, and column (3) identifies the consolidated assets of A by netting these intragroup positions from the total assets. 
Table 5: Assets Controlled by A in Each Country

\begin{tabular}{|c|c|c|c|c|c|c|c|}
\hline \multirow[t]{2}{*}{ Economy } & \multirow{2}{*}{$\begin{array}{l}\text { Total } \\
\text { assets } \\
(1)\end{array}$} & \multirow{2}{*}{$\begin{array}{l}\text { Intragroup } \\
\text { assets } \\
(2)\end{array}$} & \multirow{2}{*}{$\begin{array}{c}\text { Consolidated } \\
\text { assets controlled } \\
\text { by A } \\
(3)=(1)-(2)\end{array}$} & \multirow{2}{*}{$\begin{array}{c}\text { FDI } \\
\text { positions by } \\
\text { UHC } \\
\text { (4) }\end{array}$} & \multicolumn{3}{|c|}{ Extra-group financing } \\
\hline & & & & & $\begin{array}{c}\text { Total } \\
\text { (5) }\end{array}$ & $\begin{array}{l}\text { Equity } \\
\text { (6) }\end{array}$ & $\begin{array}{c}\text { Debt } \\
\text { (7) }\end{array}$ \\
\hline 1 & 750 & 250 & 500 & 0 & 500 & 200 & 300 \\
\hline 2 & 490 & 400 & 90 & -250 & 340 & 0 & 340 \\
\hline 3 & 340 & 40 & 300 & 160 & 140 & 0 & 140 \\
\hline 4 & 200 & 0 & 200 & 140 & 60 & 10 & 50 \\
\hline Total & 1,780 & 690 & 1,090 & 50 & 1,040 & 210 & 830 \\
\hline
\end{tabular}

The total financing reveals the extent to which A has leveraged its direct investment (in column (4)) to control a much larger amount of assets. It also reveals the extent to which it relies on extragroup financing (column (5), broken out between equity (6) and debt (7)). This includes both the equity in A itself as well as the equity investment that enterprise $\mathrm{Z}$ has in enterprise $\mathrm{E}$. It also reveals the extent of debt at A's foreign subsidiaries, particularly the reliance on extragroup financing through its subsidiary B.

It is important to note that the nationality/group consolidated statistics are not a substitute for, but rather a complement to, the residency-based financial statistics. The residency-based FDI statistics capture cross-border intra-group financing and are a starting point to analysing the international exposures of MNEs. However, it is not a complete picture because the MNE parent controls assets and incurs liabilities through its foreign affiliates. Residency-based financial statistics are useful to know where financial claims and liabilities are created and held. However, to know who makes the underlying decisions, who reaps the benefits, and who takes on the risk and needs to hold sufficient capital to cover potential losses, data are needed on a nationality basis.

\subsection{Income-in-transit}

Just as capital can flow down an MNE ownership structure, income can flow up it. The same concept of pass-through capital used for positions can be used for FDI income: income-in-transit is the FDI income a foreign-owned parent receives from its foreign affiliates. In the same way therefore, bilateral income-in-transit flows can exaggerate the degree of interdependence between partners and give a misleading picture of the importance that productive activity (in particular with respect to GDP) in one country (and its resident affiliates) makes to the generation of income in another (especially the parent). In addition it blurs the ability to identify where the income was generated within an MNE, and so, in turn, hampers analyses of GVCs and also our understanding of potential income shifting occurring under BEPS. 


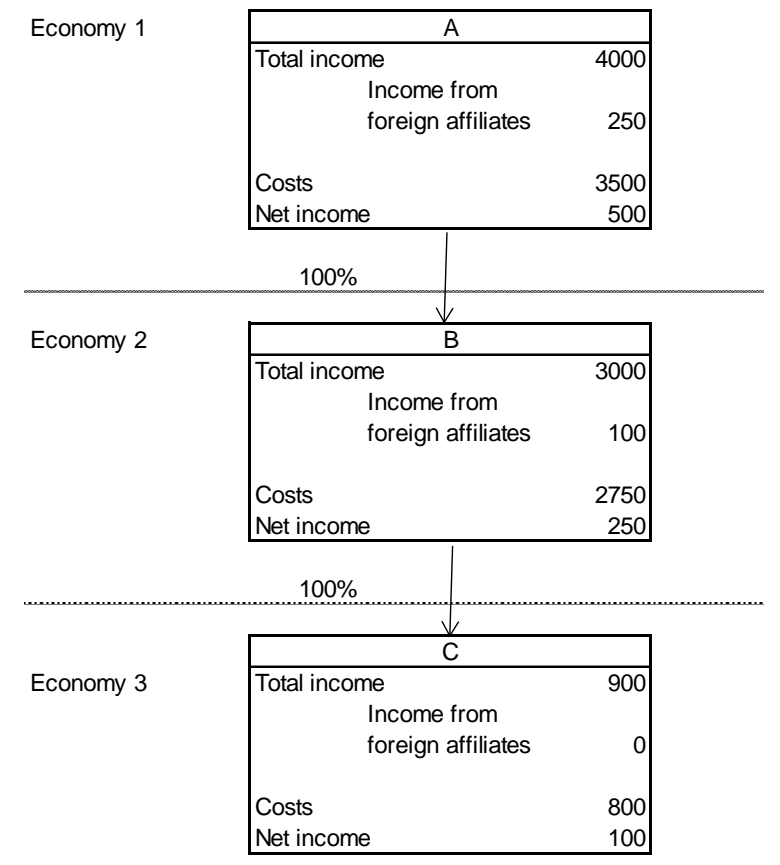

Table 6: FDI income by immediate partner country and consolidated income by ultimate partner country

\begin{tabular}{|c|c|c|c|c|c|c|c|c|c|c|c|c|}
\hline \multirow{4}{*}{$\begin{array}{l}\text { Partner } \\
\text { country }\end{array}$} & \multicolumn{12}{|c|}{ Reporting economy } \\
\hline & \multicolumn{6}{|c|}{ Standard FDI statistics by immediate partner } & \multicolumn{6}{|c|}{ Consolidated FDI statistics by ultimate partner } \\
\hline & \multicolumn{2}{|c|}{ Economy 1} & \multicolumn{2}{|c|}{ Economy 2} & \multicolumn{2}{|c|}{ Economy 3} & \multicolumn{2}{|c|}{ Economy 1} & \multicolumn{2}{|c|}{ Economy 2} & \multicolumn{2}{|c|}{ Economy 3} \\
\hline & Out & $\ln$ & Out & $\ln$ & Out & $\ln$ & Out & $\ln$ & Out & $\ln$ & Out & $\ln$ \\
\hline 1 & 0 & 0 & 0 & 250 & 0 & 0 & 0 & 0 & 0 & 150 & 0 & 100 \\
\hline 2 & 250 & 0 & 0 & 0 & 0 & 100 & 150 & 0 & 0 & 0 & 0 & 0 \\
\hline 3 & 0 & 0 & 100 & 0 & 0 & 0 & 100 & 0 & 0 & 0 & 0 & 0 \\
\hline Total & 250 & 0 & 100 & 250 & 0 & 100 & 250 & 0 & 0 & 150 & 0 & 100 \\
\hline
\end{tabular}

But by netting flows between affiliated enterprises it is possible to derive a meaningful estimate of the actual FDI income generated within the host economy (as opposed to the total income passing through). Figure 4 presents a simple example of an MNE ownership structure with three economies to illustrate this. For each entity, an abridged income statement showing their total income, total costs, and net income is shown; additionally, under the total income, the amount of that income that represents income resulting from their equity investments in other parts of the MNE, called "Income from foreign affiliates", is shown. Table 6 shows the FDI income that would be reported by immediate partner country in standard FDI statistics and the consolidated FDI statistics by ultimate partner country.

As with the positions, the total amount of income recorded in the consolidated statistics is equal to the earnings of the MNE from its foreign operations, and, so, the double-counting resulting from incomein-transit has been removed. The amounts shown for income payments for economies 2 and 3 represent the income generated within their economies and are allocated to economy 1 , who ultimately has the claim on the earnings. 


\subsection{Pass-through capital in financial flows}

Another method that FDI statisticians have used to produce estimates of pass-through capital in response to the concerns expressed by data users is to identify the capital coming into and passing out of a direct investment enterprise in the same period (Kocerka and Makowski (2017) and Montvai (2016)). As Blanchard and Acalin (2016) noted, these estimates do not appear to completely resolve the problem of pass-through capital. An important issue that arises when trying to identify capital coming into and going out of the same enterprise is timing. As the Swiss National Bank (2017) noted in its analysis of pass-through capital, it can be a gradual process.

Another issue is that the method of identifying flows going in and out will not identify pass-through capital resulting from the acquisition of domestic MNEs (as discussed above). The acquisition of a domestic MNE can involve a significant inward FDI flow but much of this could represent funds to purchase assets in other countries that are part of the MNE; since they are already owned by the domestic parent, there would be no subsequent outflows to those foreign affiliates associated with this transaction. For example, in 2016, when Annheuser Busch InBev acquired SAB Miller for USD 103 billion, there was a large inflow to the United Kingdom, where SAB Miller was headquartered, but much of those funds were payment for the operations of SAB Miller outside of the United Kingdom; there were no outflows from the United Kingdom or inflows to those countries because the assets were already foreign-owned. Defining pass-through capital as is done in this paper would recognise that a substantial portion of that inward flow was for foreign assets and would produce a smaller estimate of genuine FDI to the United Kingdom from that transaction. Leino and Yrkko (2014) provide a good example of the impact this can have on measures of pass-through capital as they measure pass-through capital based on positions ${ }^{10}$ as well as according to the difference between inflows and outflows to direct investment enterprises in a given year. They find that between 2002 and 2011, the accumulated pass-through flows were $€ 5.7$ billion, but the increase in the stock of pass-through investments was almost $€ 12$ billion. They attribute this difference to the acquisitions of Finnish MNEs by foreign investors.

In theory, the definition of pass-through capital in financial flows can be derived from the pass-through positions because the change in these positions between two periods would be the result of valuation changes and pass-through financial flows. However, the interpretation of these flows would be complicated because there would not necessarily be any flows recorded in the standard FDI statistics due to differences in timing.

\subsection{Producing consolidated FDI statistics}

The statistics separately identifying pass-through capital could be produced by FDI statisticians by linking the inward and outward FDI position and income statistics at the micro level. The compilers would then be able to see the outward positions and income receipts and inward positions and income payments for foreign-owned parents and to calculate how much of the position is located and income is generated within the economy rather than passing through. As a first step, and subject to the usual confidentiality restrictions, countries could identify the FDI outward position and income receipts of all foreign-owned parents, and not just SPEs, in their outward investment statistics. Then, data users interested in identifying the pass-through capital and income in transit could use this published information. The Austrian Central Bank and the Swiss National Bank already publish such statistics.

\footnotetext{
${ }^{10}$ Their preferred measure of pass-through capital adjusts for the source of funding by using the portion of FDI liabilities in total liabilities to determine the amount of pass-through capital.
} 


\subsubsection{Differentiating different types of pass-through capital}

The definition of pass-through capital proposed here would cover all of the types of pass-through capital within the firm discussed in the taxonomy discussed above (section 1.1). However, some of those types can have significant impacts on the host economy while others will not. Therefore, it could be useful to differentiate between these different types. However, it is not possible for the statistician to ask the motivation behind the pass-through capital to determine what type it is. It is also possible that passthrough capital serves several purposes within the MNE structure at the same time. As such, it may not be possible to completely differentiate between all of the different types. Given the motivation for separately identifying pass-through capital is to derive better measures to understand the impact of FDI on an economy, the total pass-through capital within the firm could be divided into two categories. The first is that with little direct impact on the host economy but that could have significant indirect impacts on specific sectors of the economy, including financial, legal and tax planning services. This category would include FDI for tax avoidance, expropriation or "political" risk, and protection from claims against the parent. The second category is that which is likely to involve more real economic activity in the host economy and would include pass-through capital associated with reducing transactions costs and inherited ownership structures.

Distinguishing between these two broad categories would involve looking at some characteristics of the enterprises involved to gauge the importance of real versus financial activity in the enterprise, such as assets per employee, tangible assets per employee, importance of royalties and license fee income in total income, and economic activity, It would also be possible to look at the characteristics of the country involved, such as whether it offers preferential tax rates; protections to foreign investors, such as through investment treaties or equivalent arrangements; and whether it has deep capital markets and a large financial services sector. Because these forms of pass-through capital take place within the firm, they could be addressed solely within FDI statistics.

For pass-through capital that goes outside the firm (section 1.2), there is a need to look beyond the intrafirm transactions to other functional categories to define pass-through capital. Such a definition is beyond the scope of this paper. However, as a first step, it is possible to think about a set of statistics that capture the full financing of the MNE, both internal and external, that could be the basis for considering pass-through capital that comes from outside of the firm. The concepts and definitions of such a set of statistics are discussed further below.

\subsubsection{Attribution to the Ultimate Partner Country}

To compile the statistics by UIC, the inward positions (with pass-through capital removed) could be reallocated as recommended in BD4 for traditional FDI statistics. BD4 recommends that the UIC be determined by the country of the entity that ultimately controls the investment by proceeding up the direct investor's ownership chain, until an entity that is not controlled by another entity is reached. This is akin to the ultimate beneficial owner (UBO) of the investment, and the UBO is generally considered to be the best concept for use with financial statistics. However, there are alternative concepts. One of the most well-known is the Ultimate Controlling Investor used in AMNE/FATS statistics. The Ultimate Controlling Investor is the entity that controls the direct investment enterprise. For some countries, the information on the country of the Ultimate Controlling Investor is available and can be used relatively easily to generate FDI statistics by ultimate investor. However, because the Ultimate Controlling Investor is only available for majority-controlled enterprises, it cannot be used for attributing minority investments to the ultimate investor.

The determination of the nationality of MNEs is becoming more difficult as more and more companies separate their global headquarters from their operational headquarters. For example, Shire Plc, a large 
pharmaceutical firm, has its Group Headquarters in Ireland, its International Operational Headquarters in Switzerland, and its Registered Office in Jersey. ${ }^{11}$ The global group headquarters generally follow the ownership structure and may be chosen for fiscal optimisation or other benefits. On the other hand, the operational headquarters would reflect where the decisions are made. The EuroGroups Register includes these two concepts: the Global Group Head is defined as a "parent legal unit, which is not controlled by any other legal unit... the global group head is the group head of the multinational enterprise group," and the Global Decision Centre is defined as "the unit where the strategic decisions referring to an enterprise group are taken.” (Eurostat, 2012).

Unlike the case for determining the UIC, where countries only need to collect information on the ultimate parent, the presentation by UHC is more problematic as it would require additional information on how flows/positions are channelled through countries, requiring some form of cross-border statistical collaboration or data collection for the MNE and all of its affiliates in the compiling country. Very few countries currently collect these data as either part of their FDI or FATS data collections. However, initiatives by international organisations, such as the Eurogroups Register, the U.N. Global Group Register, the Eurostat initiative on profiling large and complex MNEs, and the forthcoming OECD ADIMA database (OECD, 2018), could provide important information to compilers to help them reallocate their outward positions to the UHC as well as to reallocate inward positions to the UIC. The use of common registers would also help to ensure that all countries are using the same information when doing the reallocation.

The presentation of consolidated FDI positions by ultimate partner country could be extended to the related FDI income receipts and payments. This would be very useful information for the analysis of where income is generated along GVCs and where it accrues.

\section{Estimates of pass-through capital and its key characteristics}

\subsection{Estimates of the prevalence of pass-through capital}

To assess the importance of pass-through capital through operating affiliates one needs good quality firm level microdata. Such information, covering the entire activity of an MNE and its affiliates across borders, is not typically available or publishable by national statistics authorities. However, Bureau van Dijk's Orbis database provides financial information on enterprises in 158 countries and also includes detailed information on their ownership structure. So, it is possible to use these data to derive broad estimates of the extent of pass-through capital using the methods described above.

For this exercise, Orbis data for some of the European members of the OECD were examined to assess the extent of capital passing through 'operating entities' (as opposed to SPEs) as most of these countries already produce FDI statistics that separately identify the FDI associated with SPEs. ${ }^{12}$ The data appendix provides detail on the data from Orbis and how it was used to identify non-SPE entities potentially used to pass capital to other parts of the MNE.

To estimate the importance of pass-through capital, the first step is to identify all of the direct investors in Orbis from a country and to calculate the total amount of shareholders' funds these direct investors

\footnotetext{
${ }^{11}$ Information extracted from: https://www.shire.com/contact-us. Last accessed: August 31 2018.

${ }^{12}$ It was decided to focus on European countries as they are generally considered to have among the best coverage in Orbis. Data were used for the following countries: Austria, Belgium, Czech Republic, Denmark, Estonia, Finland, France, Germany, Hungary, Iceland, Ireland, Italy, Luxembourg, Netherlands, Norway, Poland, Portugal, Slovak Republic, Slovenia, Spain, Sweden, Switzerland, and the United Kingdom.
} 
hold in their foreign subsidiaries; entities that appear to be SPEs are dropped from the Orbis sample to focus on capital passing through operating affiliates. Once all of the enterprises with foreign subsidiaries were identified, their ownership percentage in their foreign subsidiaries was multiplied by the shareholders' funds to estimate the equity claim the direct investors had on the subsidiaries. Then, equity claims tied to the same enterprise group were aggregated at the shareholder level.

The next step is to use the information on the Global Ultimate Owner (GUO) included in Orbis to identify the direct investors in the country that are, in fact, ultimately controlled by an investor in another country. For these foreign-owned parents, the different options for the direction of pass-through (or zero-pass-through) were evaluated as in equations (1) to (3). Data was summed across firms for each country, and the ratio of pass-through equity over total equity for its resident direct investors was derived. Then, this ratio (calculated from the Orbis data) is applied to the official outward FDI statistics of the country to develop an estimate of the total amount of pass-through capital in the economy. The official FDI statistics used exclude resident SPEs to focus on the pass-through capital through operating affiliates.

This provides a broad estimate of the amount of pass-through capital in the economy. These estimates are broad partly because they rely on certain assumptions as highlighted above but also for other reasons. First, they only consider equity and not debt because the Orbis data do not provide information on intragroup lending. As such, the estimates assume that debt financing follows the same pass-through pattern as equity financing. Second, the method used to drop possible SPEs from the Orbis data was based only on industry codes and, thus, likely captured some non-SPEs while also missing some SPEs in other cases. Finally, it is not known how representative the samples are for each country. Overall, the sample from Orbis covered about one-quarter of the outward positions of the countries examined. The coverage of outward investment by region varied, reflecting differences in country coverage in Orbis; the coverage of outward investment to the European region tended to be higher than other regions. The Data Appendix provides information on coverage by country. Nevertheless, the goal was only to give an indication of how important the phenomenon of pass-through capital is.

Table 7 presents evidence for 2015 on the importance of pass-through capital for each country. The first column is the estimate of pass-through capital through operating affiliates estimated as described above; it is presented as a share of the total inward position in the country excluding resident SPEs. To compare to the importance of pass-through capital through SPEs, the last column shows the share of SPEs in the total inward investment position of each country as reported in their official statistics. ${ }^{13}$

Only a few countries have published information that can serve as a basis for comparison to these estimates. Switzerland is the most problematic as the Swiss National Bank estimates that 53 percent of the inward position in 2016 is pass-through capital under a broad definition that capture both SPEs and operating affiliates (Swiss National Bank, 2017). This could be because the coverage of Swiss companies in Orbis is not representative. For Austria, the estimates look reasonable as the Austrian Central Bank estimated that about half of the inward FDI position, excluding SPEs, represented passthrough capital in 2012 (Austrian Central Bank, 2015). This could reflect Austria's role as a gateway to investment in Central and Eastern Europe (Cernohous, 2017). As mentioned above, Leino and Yrrko (2014) estimate that about 28 percent of the inward investment position is pass-through, so the estimate here looks a little low. For Ireland, the Central Statistics Office estimates that foreign-owned direct

${ }^{13}$ Countries with $0 \%$ of outward investment accounted for by SPEs either do not host SPEs or they are insignificant. Data on SPEs are currently not available for Ireland; the United Kingdom publishes FDI statistics on SPEs with its annual detailed statistics but not the aggregate statistics, making it difficult to reconcile the data when there are differences in vintages between the two sets of statistics. 
investors accounted for about two-thirds of FDI liabilities in 2014 (Lane, 2015). The estimate in table 7 is lower, but it should be noted that their estimate includes liabilities in Ireland as well as pass-through liabilities. In addition, the estimated share from Orbis excluded SPEs but the FDI position includes resident SPEs, so pass-through via SPEs may not be accounted for in the estimate.

Table 7: Importance of pass-through entities 2015

\begin{tabular}{|c|c|c|}
\hline Reporting country & $\begin{array}{l}\text { Share of pass-through capital in inward } \\
\text { positions, excluding resident SPEs }\end{array}$ & $\begin{array}{l}\text { Share of SPEs in inward } \\
\text { investment positions }\end{array}$ \\
\hline Austria & $51 \%$ & $32 \%$ \\
\hline Belgium & $54 \%$ & $5 \%$ \\
\hline Czech Republic & $6 \%$ & $0 \%$ \\
\hline Denmark & $59 \%$ & $19 \%$ \\
\hline Estonia & $14 \%$ & $3 \%$ \\
\hline Finland & $13 \%$ & $0 \%$ \\
\hline France & $18 \%$ & $0 \%$ \\
\hline Germany & $9 \%$ & $0 \%$ \\
\hline Greece & $43 \%$ & $0 \%$ \\
\hline Hungary & $27 \%$ & $57 \%$ \\
\hline Iceland & $7 \%$ & $30 \%$ \\
\hline Ireland & $31 \%$ & n.a. \\
\hline Italy & $23 \%$ & $0 \%$ \\
\hline Latvia & $6 \%$ & $0 \%$ \\
\hline Luxembourg & $55 \%$ & $94 \%$ \\
\hline Netherlands & $65 \%$ & $82 \%$ \\
\hline Norway & $23 \%$ & $1 \%$ \\
\hline Poland & $3 \%$ & $1 \%$ \\
\hline Portugal & $15 \%$ & $11 \%$ \\
\hline Slovakia & $2 \%$ & $0 \%$ \\
\hline Slovenia & $10 \%$ & $0 \%$ \\
\hline Spain & $14 \%$ & $5 \%$ \\
\hline Sweden & $23 \%$ & $7 \%$ \\
\hline Switzerland & $2 \%$ & $14 \%$ \\
\hline United Kingdom & $21 \%$ & n.a. \\
\hline
\end{tabular}

n.a. Not available.

Source: OECD FDI Statistics database and author calculations based on Orbis.

The extent of pass-through capital varies significantly across countries. Figure 5 plots the values in table 7 sorted by the share of resident SPEs in the inward position of countries. Some countries with significant presence of SPEs, such as Luxembourg, Hungary and the Netherlands, also have high rates of capital passing through operating affiliates as MNEs find it beneficial to take advantage of the benefits that these countries offer through their operating affiliates as well as by establishing SPEs. For other countries, including Austria, Denmark and Belgium, we estimate a greater amount of pass-through in operating affiliates than in SPEs. Some countries with little or no presence of SPEs have significant pass-through capital through operating affiliates, including Greece, Italy, and France.

Figure 6 presents the total inward FDI positions for these countries between 2007 and 2015; the dark blue bars represent the standard inward FDI positions excluding resident SPEs as reported to the OECD. The light blue bars represent the consolidated FDI positions as estimated in this paper. Overall, the consolidated positions are about one-quarter lower than the standard positions. They also grew less over the period: the 2015 consolidated position is 51 percent higher than the 2007 position while the 2015 
standard FDI position is 58 percent higher than the 2007 position, indicating that pass-through capital could have been growing faster than 'real' FDI.

Figure 5: Comparing pass-through capital in SPEs and operating affiliates, 2015

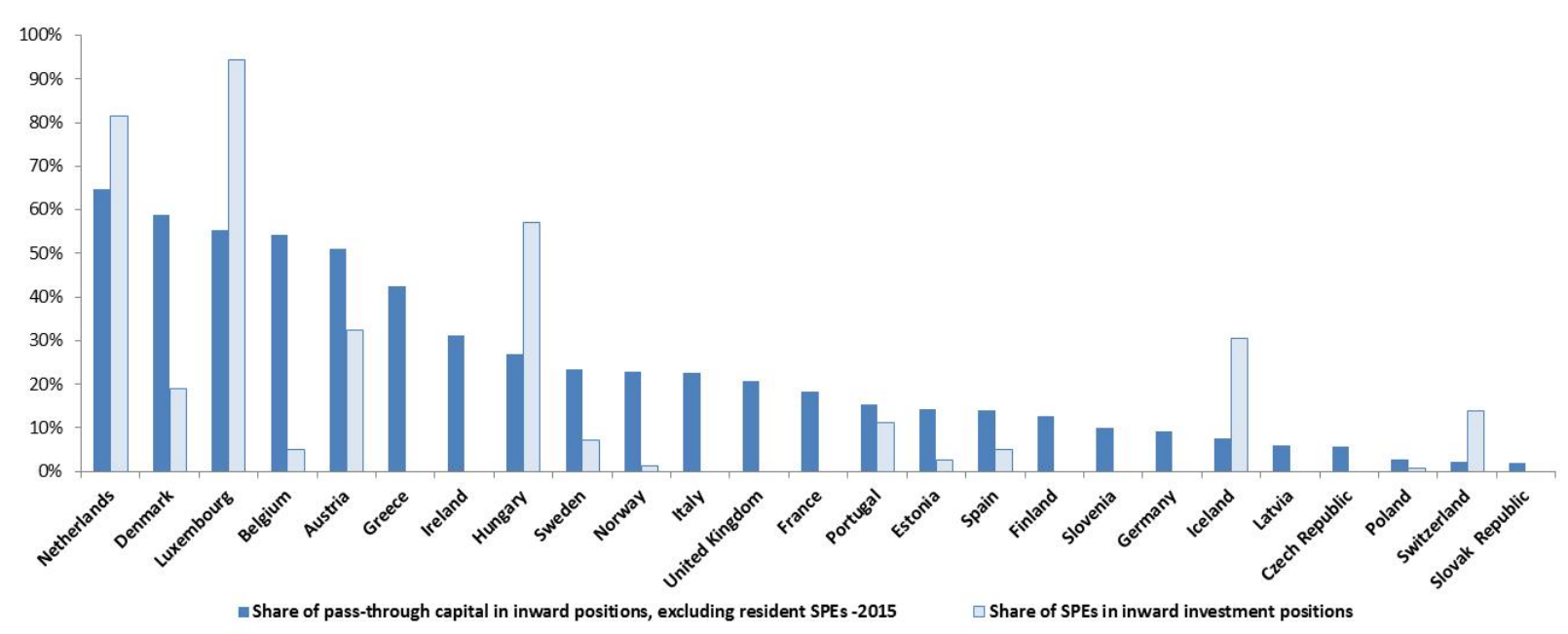

Source: OECD FDI Statistics database and author calculations based on Orbis

Figure 6: Inward FDI Positions Excluding SPEs and Consolidated Positions, 2007-2015

\section{(millions of euros)}

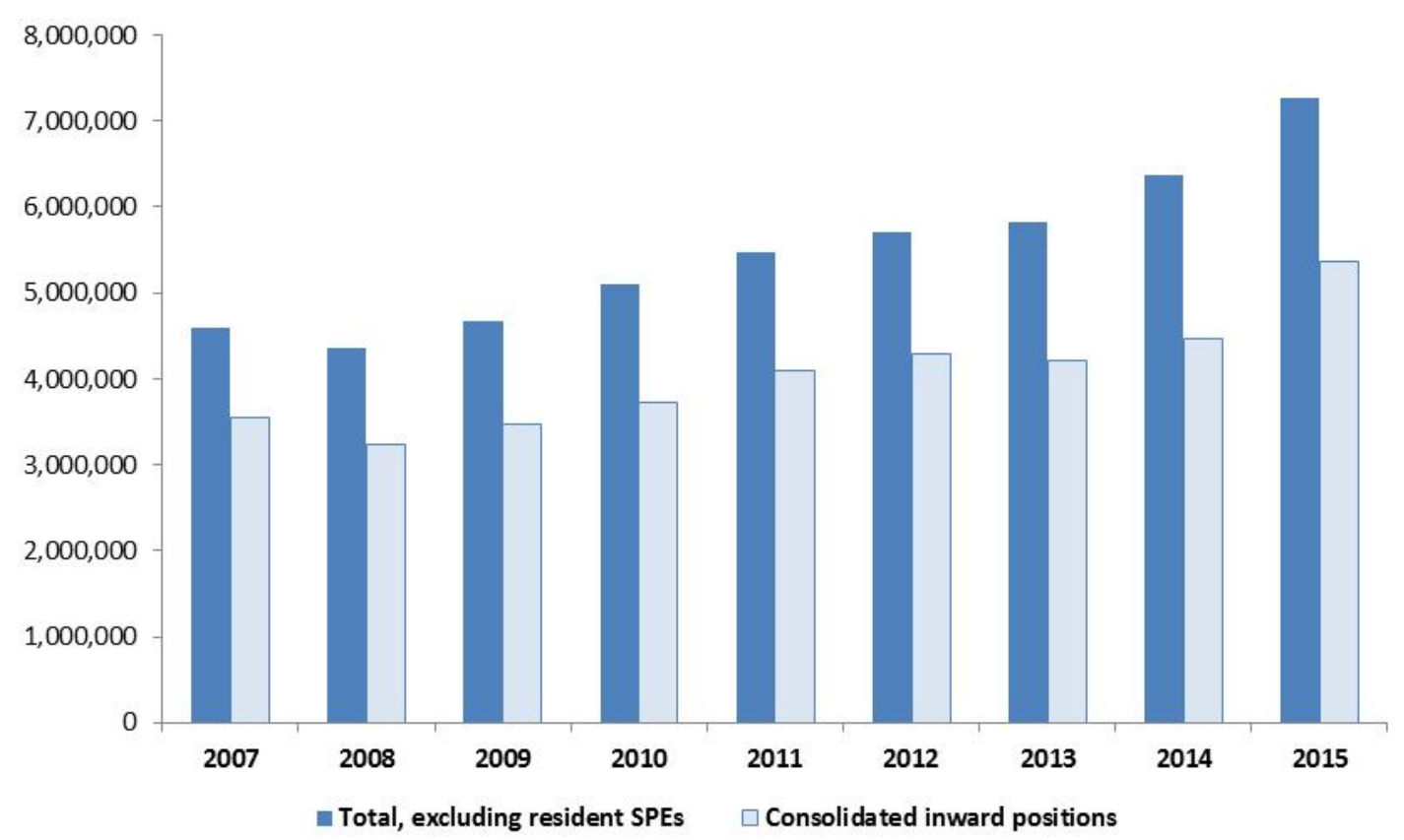

Source: OECD FDI Statistics database and author calculations based on Orbis 


\subsection{Key features of pass-through entities}

One conclusion from section 1 is that pass-through entities may differ from their purely domestic counterparts, especially in terms of the size of their balance sheets as their pass-through activities would tend to increase the size of their financial assets and liabilities. In addition, given the different motivations for pass-through, MNEs from some countries may be more likely to employ complex ownership structures than from other countries. Data from Orbis can shed light on these issues by describing patterns in the types of entities involved in pass-through as well as the origin of pass-through countries globally.

In the Orbis sample, it is possible to compare the pass-through entities (that is, foreign-owned parents) to the purely domestic parents. As Figure 7 shows, pass-through entities had about 50\% higher fixed assets per employee than purely domestic parent companies, but their total assets per employee were more than two times higher in 2015. This is consistent with these entities having much larger financial assets. When examining the data by country, this pattern held in only half of the countries in the sample, but the results are not shown given concerns about the small sample sizes for some countries due to missing employment data in Orbis.

Figure 7: size and profitability metrics for pass-through and non pass-through firms, 2015

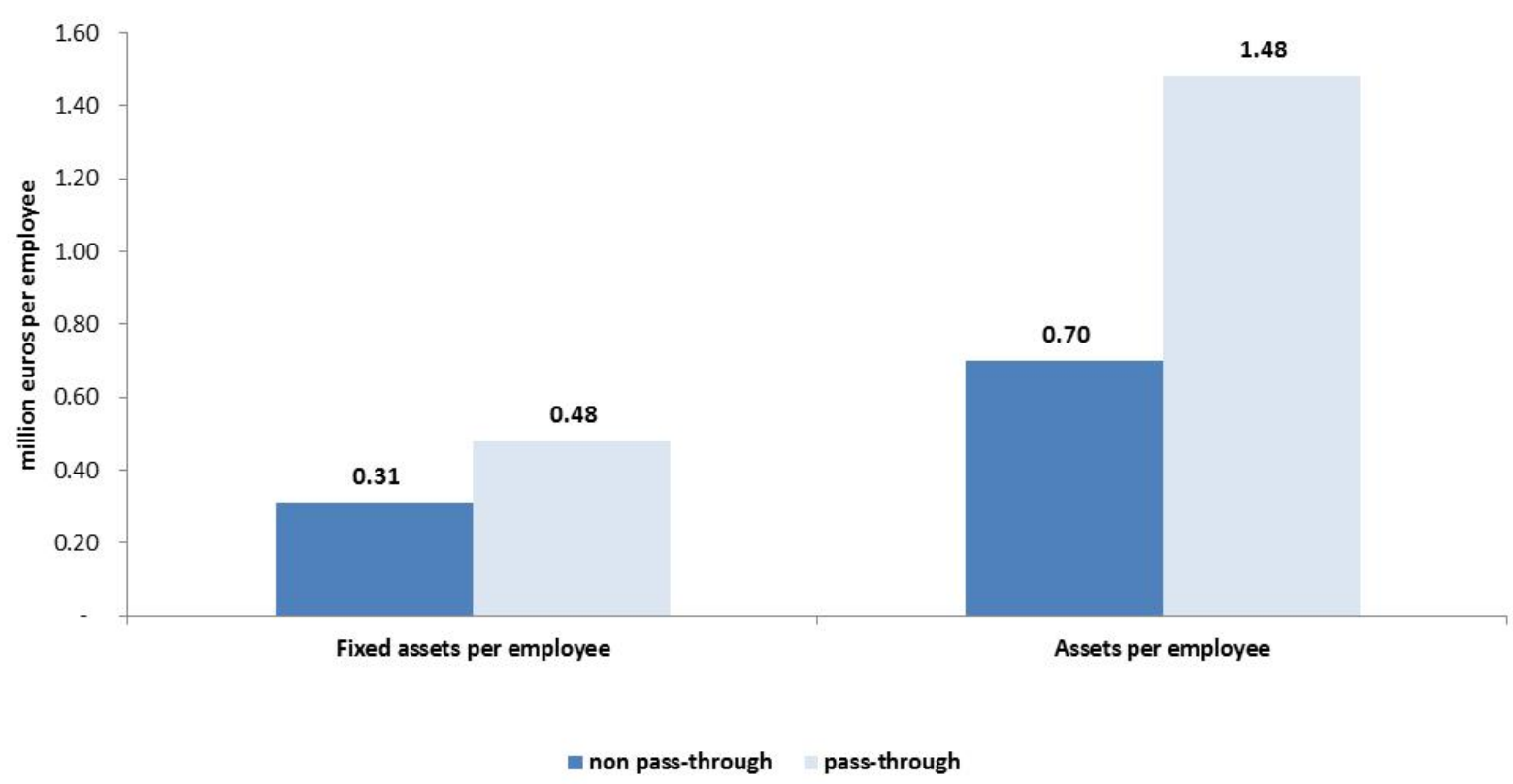

Source: Author calculations based on Orbis

The data in Orbis can also provide information on the country of the Ultimate Investor of the MNE Group. An examination of these data reveals that US MNEs appear to be more involved in pass-through activity than MNEs from other countries. For example, in 2015, US-owned MNEs accounted for about 25 percent of all pass-through firms in the countries examined and for about 32 percent of capital (Figure 8). This is not surprising given the complexity of the ownership structures of some US MNEs. The practical impact of this is that while FDI statistics by immediate partner country would understate the importance of the United States as an investor, the reallocation of the inward position to the UIC would overstate the importance of the United States because some of that position represents funds passing through the economy. Japan, the Netherlands and other large economies in Europe are the next most 
significant sources of pass-through capital. Looking at the earlier years (annex D), the composition and shares of UICs have stayed largely unchanged, with the exception of the United Kingdom which had a more marked presence in 2007 (17\%) than it has in 2015 (5\%). ${ }^{14}$

Figure 8: Composition of equity pass-through by Ultimate Investing Country, 2015

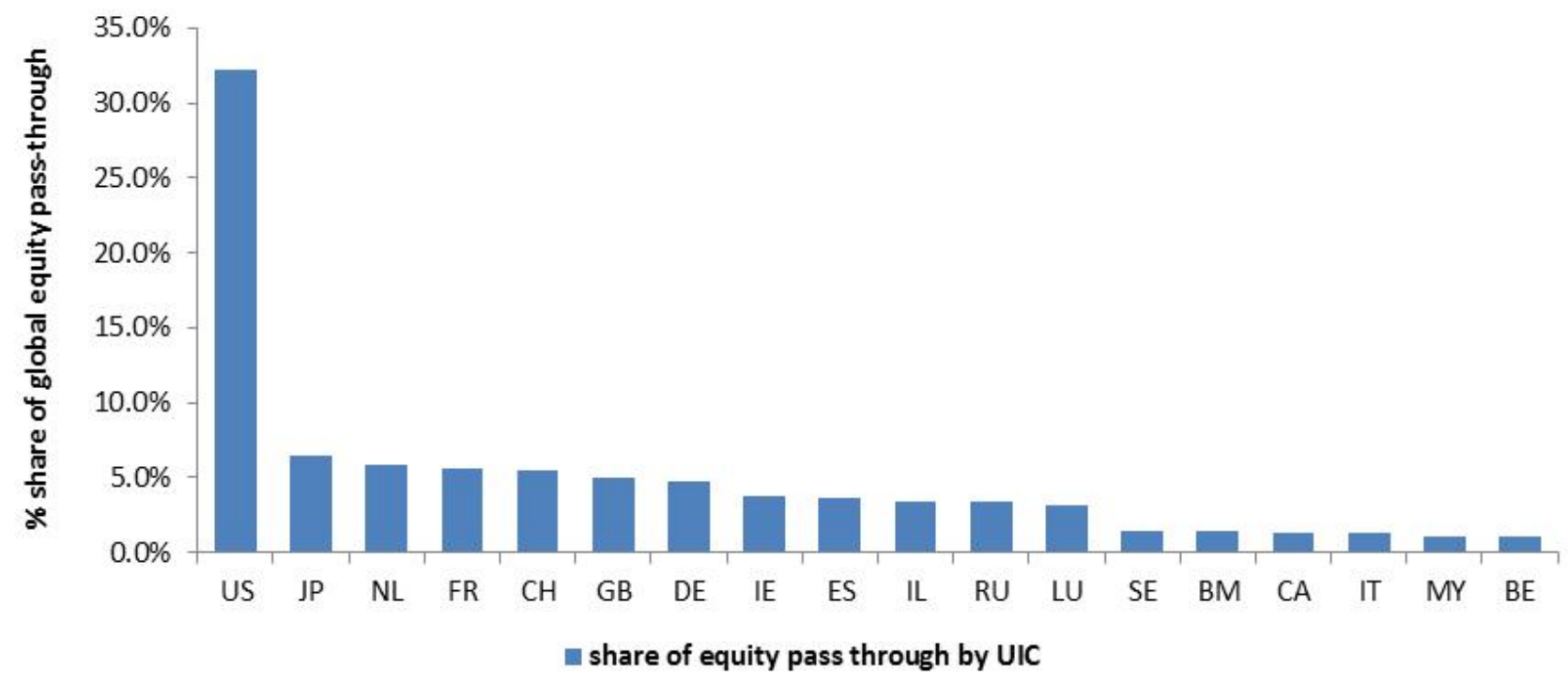

Source: Author calculations based on Orbis

Note: only UIC countries with share $>1 \%$ are shown; full data on UIC shares of equity and of number of entities is available in annex $\mathrm{D}$.

\section{Related Statistics and Measurement Issues}

This section begins by examining some related sets of statistics, including consolidated statistics as well as those on the operations of MNEs and on international investment. Then, it will examine some measurement issues that are relevant to consolidated FDI statistics but also more broadly, including determining the value and location of intangible assets.

\subsection{Related statistics}

The Bank for International Settlements publishes two sets of nationality-based statistics. The first of these is the Consolidated Banking Statistics (CBS). The CBS are collected by the country where the international bank is headquartered. While the consolidation practices vary across countries, the CBS includes claims of the bank's foreign affiliates but removes the intragroup positions. The statistics are presented on both an immediate counterparty basis as well as on an ultimate risk basis. For example, if a German bank makes a loan to a Canadian company that was guaranteed by a United States entity, then Canada would be the immediate counterparty while the United States would be the country of ultimate risk. The BIS also compiles the International Debt Securities on a nationality basis so that debt securities of foreign affiliates are attributed to the country where the MNE is headquartered. These

\footnotetext{
${ }^{14}$ It should be remarked that while the UK share in equity pass-through drops substantially from 2007 to 2015 , the percentage of direct investment enterprises that the country ultimately controls in the sample does not vary in the same way (6.6\% in 2007 and 6.7\% in 2015, as shown in section C of annex D).
} 
statistics demonstrate the contribution of nationality-based and consolidated statistics to the analysis and monitoring of financial developments.

Statistics on the activities of MNEs (AMNE/FATS statistics) are closely related to FDI statistics. To determine if the consolidating FDI statistics provided better measures of the FDI into an economy that is having a real impact on the host economy, the correlations between the inward FDI positions excluding resident SPEs and key measures of the activities of MNEs-employment, turnover, and value added - were compared to the correlations with the consolidated FDI statistics. Overall, consolidating the FDI positions yields better alignment with activity measures. Considering employment data from AMNE/FATS, for example, the R-squared with FDI positions improves from 0.73 to 0.86 after consolidation (see Figure 9). Improvements in the correlation are particularly large in Belgium, Finland, Germany, Portugal, and Sweden. In contrast, in the Netherlands, Ireland, and to a lesser extent, Hungary, and Luxembourg, the relationship between employment and FDI positions loses strength when taking pass-through into consideration.

\section{Figure 9: Correlation between employment (AMNE/FATS) and FDI Inward positions - before and after consolidation}
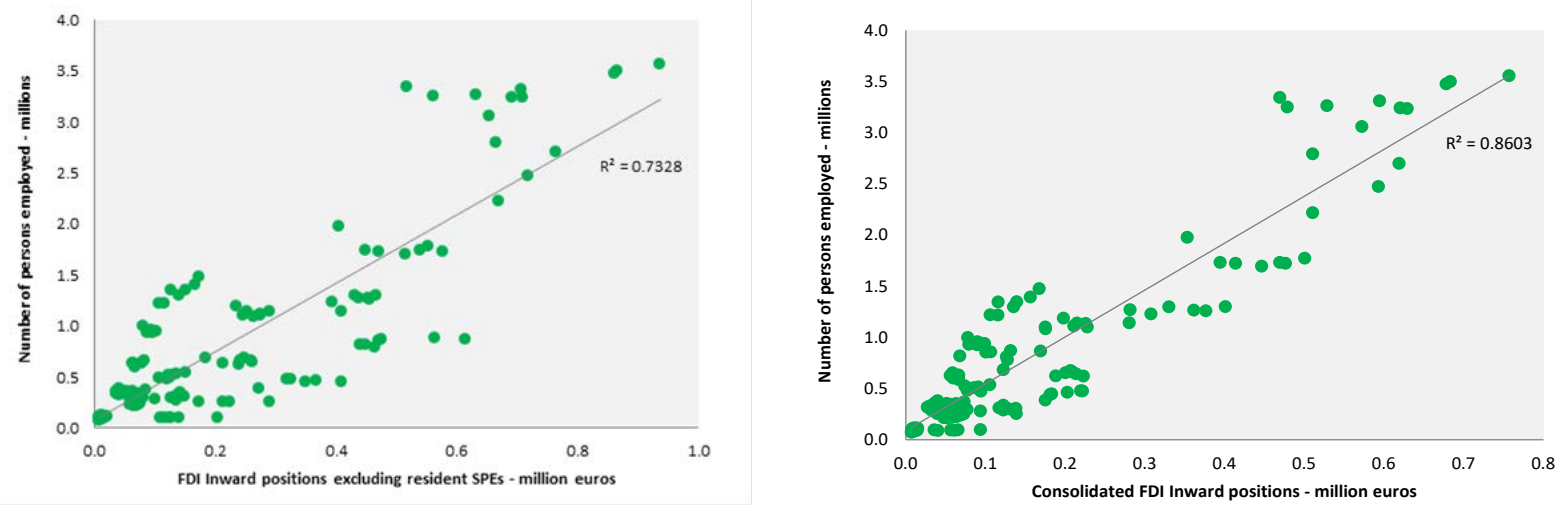

Source: OECD FDI Statistics database, OECD AMNE Statistics database, and author calculations based on Orbis.

Similarly, the analysis of FDI positions against turnover and value added data from AMNE/FATS also shows increased alignment. For turnover (top panel of figure 10), the R-Squared shows only a slight improvement, from 0.86 to 0.89 , after consolidating, while for value added (bottom panel), the relationship improves from 0.80 to 0.88 . Once again, the improvement in correlation was substantial in some countries. For turnover, consolidation increased the R-squared for Estonia and Spain while for value added, Denmark and Hungary both show a particularly stronger alignment with FATS.

The correlations between changes in the positions and changes in the activity measures were also examined to determine if changes in the consolidated statistics could provide a better indication of where MNE activity is increasing or decreasing than the traditional FDI statistics. However, the correlations were very weak with both sets of FDI statistics, and the results were mixed. This could be because changes in FDI positions reflect not only investment flows that could be associated with changes in MNE activities but also changes in valuation. 
Figure 10 : Correlation between turnover (AMNE/FATS), value added (AMNE/FATS) and FDI Inward positions - before and after consolidation
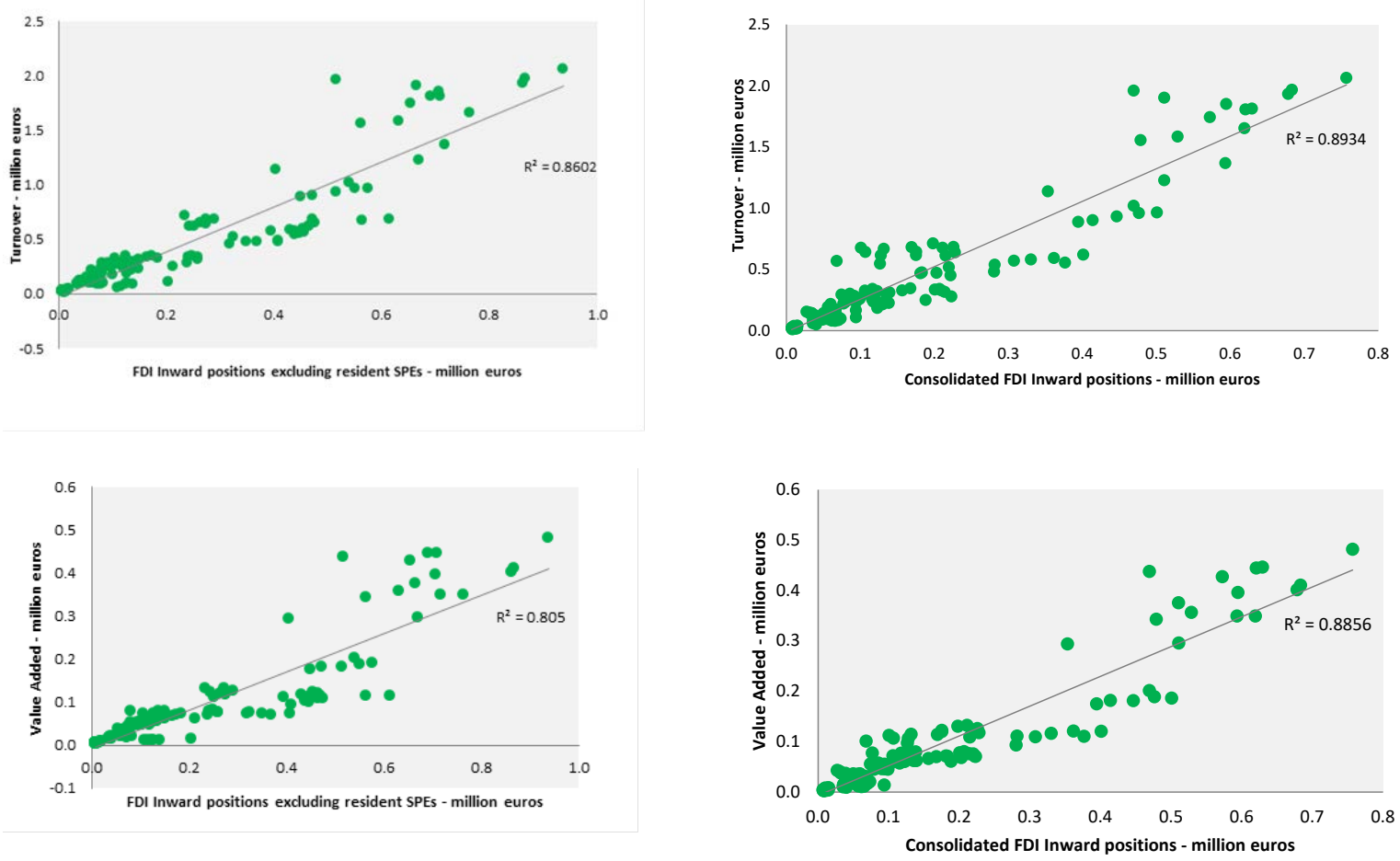

Source: OECD FDI Statistics database, OECD AMNE Statistics database, and author calculations based on Orbis.

The correlations between changes in the positions and changes in the activity measures were also examined to determine if changes in the consolidated statistics could provide a better indication of where MNE activity is increasing or decreasing than the traditional FDI statistics. However, the correlations were very weak with both sets of FDI statistics, and the results were mixed. This could be because changes in FDI positions reflect not only investment flows that could be associated with changes in MNE activities but also changes in valuation.

As noted in section 2.1.3, the WGIIS developed a framework to harmonise and align the definitions, concepts, and classifications used for FDI and AMNE/FATS statistics so that they could be used together. Use of this framework would likely further enhance the alignment between the two sets of statistics by not only focusing on the same populations but also by providing better measures of the full involvement of the MNE in the host economy.

Trade in Value Added (TiVA) statistics were developed in response to the growth of global value chains (GVCs) and increased globalisation. These statistics focus on the value added in each country in the production of goods and services that are traded. TiVA statistics identify the domestic value added of a country that ends up in foreign final demand as well as the ultimate destination for that domestic value added; similarly, they identify the foreign value added in domestic final demand as well as the ultimate source of that value added. These statistics have provided important insights into the economic relations between countries that could be obscured by the increasing complexity and globalisation of economic production (OECD and World Trade Organisation, 2015).

The OECD has been developing a methodology to integrate FDI income statistics into the TiVA Framework to understand where the income is generated along GVCs and where that income accrues (OECD, 2016). This work highlighted the limitations in FDI statistics that inhibited their use for such 
globalisation analysis, including income-in-transit and the presentation by immediate rather than ultimate partner country. The consolidated FDI statistics proposed in this paper address these issues and should enhance the integration of FDI statistics into TiVA and the ensuing analysis.

\subsection{Some remaining measurement issues}

The methodology proposed in this paper relies on being able to identify where the assets of the MNE are located so that the consolidated view of the MNE can be attributed to specific economies. While this is usually straightforward for tangible assets with some exceptions, it is much more difficult for intangible assets. MNEs can move their intangible assets to economies that offer advantages, such as concessional tax rates, while continuing to use these assets in their production in other countries. The determination of the location of intangible assets within MNEs is not straightforward (UNECE, 2015). Improved guidance on determining the location of intangible assets using economic rather than legal ownership would enable better recording of transactions and positions in intangible assets in FDI statistics. In addition, the framework developed here could be used to present the recording of intangible assets on an ownership, or nationality, basis rather than residency basis.

The value of intangible assets also poses difficulties for FDI statisticians. Market values are considered to be the appropriate valuation for FDI positions. However, in practice, market values are only available for a small portion of FDI positions because most of the equity of direct investment enterprises is not listed. As such, it is necessary for FDI statisticians to estimate market values. The international guidelines offer several methods for doing this (see Annex 10 in OECD, 2008), but most of these methods exclude intangible assets from these market value estimates. For example, the most common method used, Own Funds at Book Value, relies on the accounting records of the direct investment enterprise kept according to International Financial Reporting Standards. These standards do not include the revaluation of intangible assets. Better methods to estimate market values of FDI positions would improve the comparability across functional categories in the BOP and IIP statistics as well as better reflect the important contribution of intangibles to the value of corporations, particularly MNEs, and to global production arrangements.

Another phenomenon that has affected FDI statistics is the decision by MNEs to move their headquarters to new countries to take advantage of benefits from the relocation, such as lower taxes. This phenomenon, sometimes called redomiciliation, can result in significant FDI flows that are almost completely offset by portfolio investment flows (Irish Central Statistics Office, 2016); in addition, there is likely very little change in the actual operations of the MNE. It is possible that the methods used here to identify pass-through capital in FDI could be extended to portfolio investment to encompass these transactions. By doing so, the flows and positions associated with these transactions could be eliminated from the consolidated FDI statistics to reflect their limited impact on the economies involved.

\section{Potential Policy Issues}

Consolidated FDI statistics by ultimate partner economy would have many uses. First, they would provide better measures of financial integration between economies. By eliminating pass-through capital, the statistics would represent true financial integration and not financial intermediation between countries. In addition, the statistics by ultimate partner would provide better bilateral statistics for understanding the financial linkages between specific countries. These statistics could be used to analyse how a wide range of policies, such as trade and investment agreements and tax policies, are related to pass-through FDI or to true financial integration between countries and would help us better understand the financial interdependencies between countries. 
Second, to the extent that pass-through capital responds to tax considerations, changes in tax policy can have significant impacts on FDI flows and positions but these changes may not be associated with any real changes in their operations as they only affect the ownership structure and not their actual operations (Foley et al, 2011). With recent or forthcoming tax policy changes in several countries, including the United States, these statistics would allow for the analysis of trends in genuine FDI separately from those related to fiscal optimisation by MNEs. In broader terms, these statistics would enable a better analysis of the factors that attract FDI. Economists usually distinguish the factors that drive FDI, such as market-seeking behaviour or factor cost differences, from those that drive portfolio investment, such as monetary policy or the business cycle. Yet, Blanchard and Acalin (2016) found that the factors usually considered drivers of portfolio investment flows were more highly correlated with FDI flows to emerging markets than to portfolio investment flows to those markets. They hypothesized that this was due to pass-through capital, so consolidated FDI statistics, from which the pass-through capital has been eliminated, should enable a better analysis of the drivers of FDI.

Third, these statistics would allow for better monitoring of commitments made under international agreements, such as free trade agreements, in the area of investment by enabling the monitoring of changes in the amount of assets in the reference economy owned by the partner country. In addition, they could also be used to monitor the contribution of FDI from advanced economies to financing other international initiatives, including the Sustainable Development Goals (SDGs), the transition to a carbon neutral economy, and official development assistance. In particular, having FDI statistics that reflect the extent of FDI in the ultimate host country would allow us to better link FDI with outcomes on the SDGs, such as job creation or gender equality.

Fourth, the statistics would enable better analyses of the impact of globalisation on an economy. A key use of the statistics, for example, could be to integrate them into the extension of the Trade in Value Added (TiVA) Framework that incorporates primary income flows. Because the new statistics would more accurately measure the 'real' FDI income generated within an economy and the ultimate destination of that income, they are better related to the underlying value added generated within a given period and so are better equipped to identifying where income is generated in a global value chain (GVC) and where it ultimately accrues. Moreover, by distinguishing outward FDI positions between purely domestic parent companies and foreign-owned parent companies, the statistics would provide essential information to quantifying the benefits to home countries of their ownership of foreign production facilities.

The expanded statistics that capture intra-group as well as extra-group financing and that reflect the nationality of the firms would also have several uses. For example, these statistics could be linked to AMNE/FATS statistics to analyse the relationship between MNEs' operations and their financing; this would be especially valuable if the statistics are expanded to capture the total financing of the MNE. Such linked statistics could show, for example, if foreign-owned firms can tap into intragroup financing in times of financial crises in the host countries, thus contributing to the resilience of these economies. Similarly, it could show how crises in the home countries affect the operations of their foreign affiliates. It could also show how well aligned MNEs activities are with where they attribute the income, shedding light on profit-shifting.

Finally, these statistics would help to monitor the cross-border exposure of MNEs. A true nationality, or ownership-based approach, to measuring the cross-border exposures of MNEs would include borrowing by the foreign subsidiaries of MNEs from unaffiliated parties, either domestic or foreign. Expanding the measures beyond FDI to capture the total assets of the group would provide a more complete picture of the economic involvement of the group as well as its cross-border and local 
exposures. The nationality approach recognises that the headquarters controls many of the decisions taken by the firm. This means that some aspects of the operations of the foreign-owned firm may respond more to home country policies than host country policies. Differentiating between domestic and foreign-owned entities is necessary to understand who ultimately bears the risk (Lane, 2015). Consolidation would also be a step to developing a consolidated measure of the wealth of nations for their non-financial corporations.

\section{Conclusion and Next Steps}

MNEs play a central role in the creation and management of complex production networks. However, FDI statistics reflect not just the FDI associated with these networks but also other factors, such as fiscal optimisation to reduce tax burdens and the increasing sophistication in MNEs' capital structures. This can make it difficult to interpret FDI statistics in the sense that they are not 'real' and provide little in the way of "long-term" investments in a country. When MNEs channel investments through several countries, FDI flows and positions may be 'inflated' because each flow into and out of each country is counted even if the capital, or income, is just passing through. Moreover, this behaviour can further obscure the ultimate source and destination of FDI when the statistics are compiled by immediate partner country.

This paper proposed a method to compile consolidated FDI statistics that removes pass-through capital. Estimates of the amount of pass-through capital in operating affiliates for a selection of European members of the OECD were derived using data from the Orbis database. These estimates indicate that the amount of pass-through capital in operating affiliates, rather than in SPEs, is quite extensive, accounting for about one-quarter of the inward FDI positions excluding resident SPEs in a selection of European countries. It also appears that pass-through capital is growing faster than the 'real' FDI.

Future research will focus first on estimating pass-through capital for a greater number of countries. In addition, the possibility that information on the nationality of the MNE group could be introduced into the estimates will also be explored. These nationality-based statistics would be a complement to the residency-based FDI statistics. While residency-based financial statistics are useful to know where financial claims and liabilities are created and held, nationality based statistics provide information on who makes the underlying decisions, reaps the benefits, and takes on the risk and needs to hold sufficient capital to cover potential losses. These statistics would be useful for better measuring financial integration and the links between economies as well as possibly being used in conjunction with statistics on the operations of MNEs to analyse the relationship between the financing of MNEs and their operations. Whether it is possible to differentiate pass-through capital that has little direct impact on the host economy, such as that related to tax avoidance, from pass-through capital that does have a direct impact on the host economy, such as from reducing transactions costs, will also be explored. Finally, it would be useful to use additional information from the balance sheets included in Orbis to develop some estimates of the total assets controlled by the foreign investor in the host economies.

Nevertheless, the estimates in this paper will continue to rely on the availability of detailed micro-data that includes ownership information. It would obviously be preferable for the estimated to be based on data collected for the production of official FDI statistics. As a first step, countries could publish a limited set of data based on the nationality of the ultimate investor; that is, identifying the outward investment positions of a country accounted for by direct investors in the reporting country that are in fact foreign-owned. Ultimately, it would be useful to have countries attempt to use these methods. This could identify additional complexities in the financial structure of MNEs that need to be addressed as well as giving an indication of the feasibility of these methods. 


\section{Bibliography}

Angulo, Emma and Alicia Hierro (2017), “Asymmetries in the Coordinated Direct Investment Survey: What Lies Behind?” IMF Working Paper 17/261.

Antras, Pol, Mihir Desai, and Fritz Foley (2008), "Multinational Firms, FDI Flows and Imperfect Capital Markets,” Quarterly Journal of Economics 2008, pp. 1171-1219.

Austria Central Bank (2015), "Who is the Investor? A Simple Question that May Improve FDI Statistics," presentation to the WGIIS, 18 March 2015.

Bank for International Settlements (2015), "Consolidation and Corporate Groups: An Overview of Methodological and Practical Issues," Inter-Agency Group on Economic and Financial Statistics (IAG), IAG reference documents.

Blanchard, Olivier and Julien Acalin (2016), "What Does Measured FDI Actually Measure?", Peterson Institute for International Economics, PB16-17, October 2016.

Caballero, Julian, Ugo Panizza, and Andrew Powell, "The Second Wave of Global Liquidity: Why Are Firms Acting Like Financial Intermediaries?" Graduate Institute of International and Development Studies, International Economics Department, Working Paper HEIDWP21-2015.

Central Statistics Office of Ireland (2016), "The Impact of Redomiciled Companies on the Balance of Payments and International Investment Position."

Cernohous, Thomas (2017), "FATS and FDI Statistics: Close Connections, Different Focus," Focus on Extneral Trade 2016/2017: Foreign Direct Investment and Trends, Drivers Limiting Factors, Austrian Central Bank.

Desai, Mihir A., Fritz Foley, and James R. Hines (2003), "Chains of Ownership, Regional Tax Competition, and Foreign Direct Investment," Foreign Direct Investment in the Real and Financial Sector of Industrial Countries, edited by Heinz Herrmann and Robert Lipsey, Heidelberg: Springer Verlag, pp. 61-98.

Desai, Mihir, Fritz Foley, and James R. Hines (2006), “The Demand for Tax Haven Operations,” Journal of Public Economics, 90, pp. 513-531.

Eggelte, Juriaan, Melle Bijlsma, and Krit Cartier (2016), "What Shall We do With Pass-through? DNB's Experiences with Special Financial Institutions," mimeo, Dutch National Bank.

Eurostat (2012), Foreign AffiliaTes Statistics (FATS) Recommendations Manual, Luxembourg.

Federico, Stefano (2015), "How Does Multinational Production Affect the Measurement of Competitiveness?” presentation to the March 2015 WGIIS meeting, Paris France [DAF/INV/STAT/WD(2015)5].

Foley, Fritz C., Dhammika Dharmapala and Kristin J. Forbes. "Watch What I Do, Not What I Say: The Unintended Consequences of the Homeland Investment Act," Journal of Finance, 66, no. 3 (June 2011): 753-788. 
Gaukrodger, D. (2013), "Investment Treaties as Corporate Law: Shareholder Claims and Issues of Consistency”, OECD Working Papers on International Investment, 2013/03. OECD Publishing, Paris

International Monetary Fund (2017), "Preliminary Report of the Task Force in Special Purpose Entities," Balance of Payments Committee Meeting, BOPCOM-17/05.

International Monetary Fund (2008), Balance of Payments and International Investment Positions Manual, $6^{\text {th }}$ edition, Washington, DC.

International Monetary Fund and the Financial Stability Board (2009), "The Financial Crisis and Information Gaps,” Washington, DC.

Irish Central Statistics Office (2016), "Redomiciled PLCs in the Irish Balance of Payments," http://www.cso.ie/en/media/csoie/methods/balanceofinternationalpayments/RedomiciledPLCs. pdf.

Kocerka, Jacek and Krzysztof Makowski (2017), "Does Pass-through Funds Require Their Own Functional Category," ISI World Statistics Congress.

Lane, Philip R. (2015), "Cross-Border Financial Linkages: Identifying and Measuring Vulnerabilities," mimeo, Trinity College Dublin and CEPR.

Lane, Philip R. and Gian Milesi-Ferretti (2017), "International Financial Integration in the Aftermath of the Global Financial Crisis," International Monetary Fund, WP/17/115, May 2017.

Leino, Topias and Jyrki Ali-Yrkko (2014), "How Well does Foreign Direct Investment Measure Real Investment by Foreign-Owned Companies?", Bank of Finland, Bank of inland Research Discussion Paper No. 12/2014, May 2014.

Lewellen, Katharina and Leslie Robinsons (2013), "Internal Ownership Structures of U.S. Multinational Firms,” available at SSRN: https://ssrn.com/abstract=2273553 or http://dx.doi.org/10.2139/ssrn.2273553.

Mahoney, Paul (2007), "Developing a Consolidated Approach to Identifying Pass-through Capital and Reallocating Positions to Ultimate Investors and Ultimate Investees," paper of the Research Agenda of the OECD Workshop on International Investment Statistics, mimeo, October 2007.

Montvai, Beata (2016), "Towards Interpretable FDI Data in External Sector," Hungarian Central Bank, www.ksh.hu/cess2016/prezi/cess2016_b6_beata_montvai.pptx.

Organisation for Economic Cooperation and Development (2006), "A Method for Allocating the U.S. Direct Investment Position Abroad to the Country and Industry of Ultimate Destination," Note by the United States, Paris, France.

Organisation for Economic Cooperation and Development (2008), Benchmark Definition of Foreign Direct Investment, 4th edition, Paris, France.

Organisation for Economic Cooperation and Development (2011), "Harmonising FDI and Activities of MNE Statistics," Paris, France.

Organisation for Economic Cooperation and Development (2015), "Harmonising FDI and Activities of MNE Statistics: Feasibility of and Priorities for Compilation," Paris, France. 
Organisation for Economic Cooperation and Development (2016), "Integration of FDI Statistics in TiVA: Results and Data Challenges," Paris, France.

Organisation for Economic Cooperation and Development (2018), "Measuring MNEs using Big Data: the OECD Analytical Database on Individual Multinationals and their Affiliates (ADIMA)," Paris, France.

Organisation for Economic Cooperation and Development and World Trade Organisation (2015), "Trade in Value Added," http://www.oecd.org/sti/ind/measuringtradeinvalue-addedanoecdwtojointinitiative.htm, Paris, France.

Pohl, J. (2018), "Societal benefits and costs of International Investment Agreements: A critical review of aspects and available empirical evidence", OECD Working Papers on International Investment, No. 2018/01, OECD Publishing, Paris

Swiss National Bank (2017), Direct Investment 2016, Volume 17.

Tarashev, Nikola, Stefan Avdjiev, and Ben Cohen (2016), "International Capital Flows and Financial Vulnerabilities in Emerging Market Economies: Analysis and Data Gaps," Note submitted to the G20 International Financial Architecture Working Group, Bank for International Settlements.

Tissot, Bruno (2016), “Globalisation and Financial Stability Risks: Is the Residency-based Approach of the National Accounts Old-fashioned?”, BIS Working Paper No. 587.

United Nations Economic Commission for Europe (2015), Guide to Measuring Global Production, "Ownership of Intellectual Property Products inside Global Production," New York and Geneva.

Van Os, R., Knottnerus R. (2011) "Dutch Bilateral Investment Treaties -A gateway to "treaty shopping’ for investment protection by multinational companies”, SSRN Electronic Journal.

10.2139/ssrn.1974431 


\section{Data Annex}

To produce the estimates of pass-through capital, two datasets were used: micro-level data from Bureau van Dijk's Orbis database and aggregate FDI positions from the OECD FDI Statistics Database.

\section{A. Micro data}

The source database for this analysis is Orbis by Bureau Van Dijk. This is a cross-country firm level database containing ownership link information connecting subsidiaries through their direct owners to their ultimate (global) owners. These data are sourced from a variety of documents (company reports and accounts, stock exchange filings, and regulatory records) and includes ownership percentages, types of relationships (such as global or domestic ultimate owner) and dates related to each relationship.

The dataset was created by pooling cross sections of linkages for years 2007 to 2015. For each linkage, the variables examined were:

- $\quad$ Subsidiary identifier and country ${ }^{15}$;

- $\quad$ Shareholder identifier and country ${ }^{16}$;

- $\quad$ Global Ultimate Owner (ownership above 50\%) and country ${ }^{17}$; and

- $\quad$ Percentages of ownership (direct and total).

To be included in each cross section, the linkages had to be active in the year and entities at shareholder level (hence, the country of pass-through) were limited to be European Union and EEA countries. This was done to ensure maximum quality and timeliness of data (the higher European coverage is a wellknown feature of Orbis). Subsidiaries and Ultimate Owners were however unconstrained in terms of geographic location. The cases in which the entire ownership chain was located in the same country were removed.

Subsequently foreign-owned investors and their affiliates were identified. These are the instances of pass-through linkages. Foreign-owned investors were found using the 'GUO50' variable. Orbis identifies the GUO by following the ownership chain of the enterprise through control relationships until an entity that is not controlled by another entity is reached.

In addition, to focus on pass-through capital through operating affiliates rather than SPEs, enterprises with NACE codes 6420 and 6430 were dropped from the sample. This was a rough definition of SPE ${ }^{18}$ because it only considered the industry code and not other factors, such as the amount of employment or share of foreign assets or liabilities on their balance sheets. Financial accounts data on shareholder funds and income were then added to the database via the respective identifiers. Preference was given for subsidiaries to the unconsolidated financial statements. For the shareholders and the GUOs, priority was given to unconsolidated accounts, but where the shareholder' funds variable was not available, consolidated data were retained.

\footnotetext{
${ }^{15}$ Country was based on the two-letter ISO code prefix contained in the entity identifier. This reflects the country of registration of the firm.

${ }^{16}$ Ibid

${ }^{17}$ Ibid

${ }^{18}$ For further details, please consider, for example, the Eurostat NACE Rev.2 Introductory guidelines. Units classified in these two classes do not have any revenue from the sale of products, and usually do not employ staff (except possibly one or a few persons acting as legal representatives). Sometimes these units are called "brass plates", or "post boxes" or "empty boxes", or "special purpose entities - SPE", as they just have a name and an address.
} 


\section{A.1. Treatment of outliers and missing values}

Each cross section of data was scrutinised in order to prevent individual outliers from driving passthrough estimates. Maxima and minima by country and year were removed; in addition, data points ranked second within country-year distributions, where the ratio of the data point to the maximum or minimum exceeded $75 \%$, were also dropped.

In cases where the total ownership percentage-both direct and indirect-were missing, the direct ownership percentage was used. This means that the estimates are likely a lower bound on the amount of pass-through capital.

\section{A.2. Coverage of FDI statistics}

Orbis outward equity stock by country of immediate investor was compared to official FDI equity positions (excluding SPEs) to assess the coverage of the sample (table A.1).

Table A.1: Outward equity stock as calculated from Orbis data as share of aggregate outward FDI equity positions excluding SPEs, 2007-2015

\begin{tabular}{|l|c|c|c|c|c|c|c|c|c|}
\hline Reporting country & $\mathbf{2 0 0 7}$ & $\mathbf{2 0 0 8}$ & $\mathbf{2 0 0 9}$ & $\mathbf{2 0 1 0}$ & $\mathbf{2 0 1 1}$ & $\mathbf{2 0 1 2}$ & $\mathbf{2 0 1 3}$ & $\mathbf{2 0 1 4}$ & $\mathbf{2 0 1 5}$ \\
\hline Austria & $17 \%$ & $18 \%$ & $16 \%$ & $15 \%$ & $15 \%$ & $15 \%$ & $22 \%$ & $19 \%$ & $50 \%$ \\
\hline Belgium & $12 \%$ & $19 \%$ & $22 \%$ & $25 \%$ & $29 \%$ & $28 \%$ & $37 \%$ & $30 \%$ & $17 \%$ \\
\hline Switzerland & $23 \%$ & $15 \%$ & $14 \%$ & $14 \%$ & $18 \%$ & $15 \%$ & $14 \%$ & $13 \%$ & $13 \%$ \\
\hline Czech Republic & $19 \%$ & $10 \%$ & $29 \%$ & $7 \%$ & $-137 \%$ & $9 \%$ & $11 \%$ & $10 \%$ & \\
\hline Germany & $21 \%$ & $20 \%$ & $21 \%$ & $28 \%$ & $23 \%$ & $21 \%$ & $22 \%$ & $20 \%$ & $23 \%$ \\
\hline Denmark & $13 \%$ & $13 \%$ & $10 \%$ & $9 \%$ & $12 \%$ & $8 \%$ & & & \\
\hline Estonia & $5 \%$ & $7 \%$ & $5 \%$ & $12 \%$ & $18 \%$ & $16 \%$ & $16 \%$ & $8 \%$ & $9 \%$ \\
\hline Spain & $17 \%$ & $12 \%$ & $15 \%$ & $16 \%$ & $18 \%$ & $19 \%$ & $19 \%$ & $17 \%$ & $15 \%$ \\
\hline Finland & $27 \%$ & $18 \%$ & $18 \%$ & $35 \%$ & $31 \%$ & $21 \%$ & $29 \%$ & $23 \%$ & $35 \%$ \\
\hline France & $21 \%$ & $27 \%$ & $21 \%$ & $21 \%$ & $30 \%$ & $21 \%$ & $26 \%$ & $17 \%$ & $20 \%$ \\
\hline United Kingdom & $64 \%$ & $59 \%$ & $72 \%$ & $80 \%$ & $87 \%$ & $65 \%$ & & & \\
\hline Hungary & $6 \%$ & $5 \%$ & $8 \%$ & $17 \%$ & $3 \%$ & $4 \%$ & $16 \%$ & $8 \%$ & $14 \%$ \\
\hline Ireland & $25 \%$ & $17 \%$ & $21 \%$ & $22 \%$ & $24 \%$ & $20 \%$ & $10 \%$ & $10 \%$ & $11 \%$ \\
\hline Iceland & $26 \%$ & $7 \%$ & $30 \%$ & $34 \%$ & $32 \%$ & $16 \%$ & $14 \%$ & $10 \%$ & $0 \%$ \\
\hline Italy & $7 \%$ & $18 \%$ & $11 \%$ & $17 \%$ & $9 \%$ & $16 \%$ & $20 \%$ & $13 \%$ & $17 \%$ \\
\hline Luxembourg & $123 \%$ & $92 \%$ & $129 \%$ & $120 \%$ & $169 \%$ & $199 \%$ & & & \\
\hline Netherlands & $29 \%$ & $24 \%$ & $29 \%$ & $23 \%$ & $22 \%$ & $21 \%$ & & & \\
\hline Norway & $14 \%$ & $16 \%$ & $11 \%$ & $17 \%$ & $24 \%$ & $29 \%$ & $38 \%$ & $39 \%$ & $23 \%$ \\
\hline Poland & $2 \%$ & $4 \%$ & $6 \%$ & $8 \%$ & $8 \%$ & $10 \%$ & $8 \%$ & $11 \%$ & $12 \%$ \\
\hline Portugal & $15 \%$ & $24 \%$ & $18 \%$ & $30 \%$ & $31 \%$ & $38 \%$ & $19 \%$ & $27 \%$ & $25 \%$ \\
\hline Sweden & $35 \%$ & $27 \%$ & $41 \%$ & $24 \%$ & $27 \%$ & $28 \%$ & $48 \%$ & $46 \%$ & $31 \%$ \\
\hline Slovenia & $8 \%$ & $21 \%$ & $15 \%$ & $26 \%$ & $30 \%$ & $22 \%$ & $29 \%$ & $31 \%$ & $16 \%$ \\
\hline Slovak Republic & $26 \%$ & $47 \%$ & $43 \%$ & $23 \%$ & $45 \%$ & $32 \%$ & $30 \%$ & $56 \%$ & $48 \%$ \\
\hline
\end{tabular}

Note: Data for Austria, Hungary, the Netherlands, Iceland and Luxembourg exclude resident SPEs for the whole time series, 2007-2015.

Note: Data for Belgium, Denmark, Norway, Poland, Portugal and Switzerland exclude resident SPEs for BD4 data only.

Note: Empty cells denote confidential data or no available instrument breakdown. 
This comparison is rough as differences in valuation can result in significant asymmetries in FDI statistics (Angulo and Hierro, 2017), and there is no way to determine how the valuations of total equity in Orbis compare to the valuations in the source data countries use in compiling their FDI statistics. As a result, this comparison should be taken only as indicative of the coverage the Orbis data provide. The coverage varies across countries and over time. There is a general trend upward in coverage, reflecting the improved country coverage in Orbis in terms of both the number of countries covered and the coverage within countries. Because the European region is generally better covered in Orbis, countries with a higher share of outward investment in Europe would be expected to have higher coverage than other countries. The figures for Luxembourg likely exceed the total outward investment because the procedure for removing SPEs from Orbis did not capture all of the entities identified as SPEs by Luxembourg. The negative value for the Czech Republic in 2011 reflected a large negative value for equity in a subsidiary that was subsequently dropped in treating the data for outliers.

\section{A3. Computation of pass through capital}

The computation of pass-through capital was done in two steps:

1) Once all of the enterprises with foreign subsidiaries were identified, their ownership percentage in their foreign subsidiaries was multiplied by the shareholders' funds to estimate the equity claim the direct investors had on the subsidiaries. Then, equity claims tied to the same enterprise group were aggregated at the shareholder level.

2) The different options for the direction of pass-through (or zero-pass-through) were evaluated as outlined in 2.1.1 Data were summed by direct investor country, and the share of pass-through was than calculated by taking the ratio of pass-through equity over total outward equity positions by country.

\section{B. FDI positions}

A time series of inward and outward FDI positions from 2007 to 2015 was constructed from the OECD FDI statistics database. Statistics excluding resident SPEs were used when available. For countries that did not separately identify the FDI to and from resident SPEs in earlier years, the share of resident SPEs in the total positions for the first year the data were reported was carried back to 2007. No other adjustments were made for the implementation of BD4 so there might be other breaks in series.

The United Kingdom reports SPEs for detailed annual statistics but not for the aggregate statistics, resulting in differences in vintage that make it difficult to construct a time series.

\section{Additional descriptive statistics for Ultimate Investing Country}

The table below provides information on all countries identified as UIC's of pass-through entities and their respective shares of the equity and number of entities they account for in 2007 and 2015. 
Table 8: Composition of pass-through (equity and number of entities) by Ultimate Investing Country, 2007 and 2015

\begin{tabular}{|c|c|c|c|c|c|}
\hline & \multicolumn{2}{|c|}{2007} & \multirow[b]{2}{*}{$\begin{array}{c}\text { Country of Ultimate } \\
\text { Investor }\end{array}$} & \multicolumn{2}{|c|}{2015} \\
\hline $\begin{array}{c}\text { Country of Ultimate } \\
\text { Investor }\end{array}$ & $\begin{array}{c}\text { share of pass } \\
\text { through by } \\
\text { UIC }\end{array}$ & $\begin{array}{c}\text { share of pass } \\
\text { through } \\
\text { entities by UIC }\end{array}$ & & $\begin{array}{c}\text { share of pass } \\
\text { through by } \\
\text { UIC }\end{array}$ & $\begin{array}{c}\text { share of pass } \\
\text { through } \\
\text { entities by UIC }\end{array}$ \\
\hline United States & $25.9 \%$ & $28.1 \%$ & United States & $32.2 \%$ & $25.6 \%$ \\
\hline United Kingdom & $17.3 \%$ & $6.6 \%$ & Japan & $6.5 \%$ & $4.9 \%$ \\
\hline France & $9.4 \%$ & $6.1 \%$ & Netherlands & $5.8 \%$ & $4.9 \%$ \\
\hline Netherlands & $5.8 \%$ & $4.4 \%$ & France & $5.6 \%$ & $4.8 \%$ \\
\hline Germany & $5.7 \%$ & $8.7 \%$ & Switzerland & $5.4 \%$ & $4.3 \%$ \\
\hline Japan & $5.7 \%$ & $5.0 \%$ & United Kingdom & $5.0 \%$ & $6.7 \%$ \\
\hline Italy & $4.1 \%$ & $3.0 \%$ & Germany & $4.8 \%$ & $7.2 \%$ \\
\hline Ireland & $3.2 \%$ & $0.8 \%$ & Ireland & $3.7 \%$ & $1.1 \%$ \\
\hline Spain & $3.0 \%$ & $1.0 \%$ & Spain & $3.6 \%$ & $0.9 \%$ \\
\hline Cayman Islands & $2.8 \%$ & $0.8 \%$ & Israel & $3.4 \%$ & $0.6 \%$ \\
\hline Luxembourg & $2.1 \%$ & $4.2 \%$ & Russian Federation & $3.4 \%$ & $0.9 \%$ \\
\hline Switzerland & $1.9 \%$ & $3.8 \%$ & Luxembourg & $3.1 \%$ & $5.7 \%$ \\
\hline Australia & $1.8 \%$ & $1.3 \%$ & Sweden & $1.5 \%$ & $2.6 \%$ \\
\hline Sweden & $1.8 \%$ & $3.5 \%$ & Bermuda & $1.4 \%$ & $0.8 \%$ \\
\hline Finland & $1.4 \%$ & $1.5 \%$ & Canada & $1.3 \%$ & $1.7 \%$ \\
\hline Bermuda & $0.8 \%$ & $1.2 \%$ & Italy & $1.3 \%$ & $3.1 \%$ \\
\hline Norway & $0.8 \%$ & $1.4 \%$ & Malaysia & $1.0 \%$ & $0.2 \%$ \\
\hline Belgium & $0.8 \%$ & $2.5 \%$ & Belgium & $1.0 \%$ & $2.0 \%$ \\
\hline Canada & $0.6 \%$ & $1.1 \%$ & Saudi Arabia & $0.8 \%$ & $0.1 \%$ \\
\hline Virgin Islands (British) & $0.6 \%$ & $0.7 \%$ & Singapore & $0.7 \%$ & $0.4 \%$ \\
\hline Cyprus & $0.4 \%$ & $1.0 \%$ & Curaçao & $0.7 \%$ & $0.7 \%$ \\
\hline Curaçao & $0.3 \%$ & $1.3 \%$ & Australia & $0.6 \%$ & $0.8 \%$ \\
\hline Mexico & $0.3 \%$ & $0.1 \%$ & Cayman Islands & $0.6 \%$ & $1.5 \%$ \\
\hline South Africa & $0.3 \%$ & $0.4 \%$ & Portugal & $0.5 \%$ & $0.8 \%$ \\
\hline Greece & $0.3 \%$ & $0.2 \%$ & Norway & $0.5 \%$ & $1.6 \%$ \\
\hline United Arab Emirates & $0.3 \%$ & $0.1 \%$ & Mexico & $0.5 \%$ & $0.2 \%$ \\
\hline Singapore & $0.3 \%$ & $0.4 \%$ & China & $0.5 \%$ & $0.9 \%$ \\
\hline Austria & $0.3 \%$ & $1.4 \%$ & Cyprus & $0.3 \%$ & $1.5 \%$ \\
\hline Bahamas & $0.2 \%$ & $0.4 \%$ & United Arab Emirates & $0.3 \%$ & $0.3 \%$ \\
\hline Denmark & $0.2 \%$ & $1.4 \%$ & Poland & $0.3 \%$ & $0.3 \%$ \\
\hline Israel & $0.2 \%$ & $0.6 \%$ & Brazil & $0.3 \%$ & $0.3 \%$ \\
\hline Liechtenstein & $0.2 \%$ & $0.6 \%$ & Liechtenstein & $0.3 \%$ & $0.5 \%$ \\
\hline Iceland & $0.2 \%$ & $0.4 \%$ & India & $0.2 \%$ & $0.8 \%$ \\
\hline Russian Federation & $0.1 \%$ & $0.5 \%$ & Qatar & $0.2 \%$ & $0.1 \%$ \\
\hline Lebanon & $0.1 \%$ & $0.2 \%$ & Monaco & $0.2 \%$ & $0.2 \%$ \\
\hline Hong Kong & $0.1 \%$ & $0.2 \%$ & Virgin Islands (British) & $0.2 \%$ & $1.2 \%$ \\
\hline Korea, Republic Of & $0.1 \%$ & $0.2 \%$ & Denmark & $0.2 \%$ & $1.0 \%$ \\
\hline India & $0.1 \%$ & $0.6 \%$ & Korea, Republic Of & $0.2 \%$ & $0.2 \%$ \\
\hline Saudi Arabia & $0.1 \%$ & $0.1 \%$ & Austria & $0.2 \%$ & $1.6 \%$ \\
\hline Hungary & $0.1 \%$ & $0.1 \%$ & Lithuania & $0.2 \%$ & $0.1 \%$ \\
\hline Malta & $0.1 \%$ & $0.2 \%$ & Thailand & $0.1 \%$ & $0.1 \%$ \\
\hline Czech Republic & $(*)$ & $0.1 \%$ & Bahamas & $0.1 \%$ & $0.3 \%$ \\
\hline Taiwan & $(*)$ & $0.3 \%$ & South Africa & $0.1 \%$ & $0.3 \%$ \\
\hline China & $(*)$ & $0.2 \%$ & Egypt & $0.1 \%$ & $0.1 \%$ \\
\hline Cote D'Ivoire & $(*)$ & $(*)$ & Hungary & $0.1 \%$ & $0.2 \%$ \\
\hline Kuwait & $(*)$ & $0.3 \%$ & Turkey & $0.1 \%$ & $0.2 \%$ \\
\hline Malaysia & $(*)$ & $0.1 \%$ & Venezuela & $0.1 \%$ & $(*)$ \\
\hline Portugal & $(*)$ & $0.4 \%$ & Taiwan & $0.1 \%$ & $0.3 \%$ \\
\hline Slovakia & $(*)$ & $0.2 \%$ & Hong Kong & $0.1 \%$ & $0.4 \%$ \\
\hline
\end{tabular}




\begin{tabular}{|c|c|c|c|c|c|}
\hline Poland & $(*)$ & $0.1 \%$ & Finland & $0.1 \%$ & $0.8 \%$ \\
\hline Turkey & $(*)$ & $0.1 \%$ & Panama & $0.1 \%$ & $0.3 \%$ \\
\hline Lithuania & $(*)$ & $(*)$ & Lebanon & $0.1 \%$ & $0.2 \%$ \\
\hline Slovenia & $(*)$ & $0.1 \%$ & Libyan Arab Jamahiriya & $0.1 \%$ & $(*)$ \\
\hline Brazil & $(*)$ & $0.1 \%$ & Malta & $(*)$ & $0.3 \%$ \\
\hline Mauritius & $(*)$ & $0.1 \%$ & Gibraltar & $(*)$ & $0.1 \%$ \\
\hline Saint Kitts And Nevis & $(*)$ & $0.1 \%$ & Ukraine & $(*)$ & $0.2 \%$ \\
\hline Barbados & $(*)$ & $0.1 \%$ & Croatia & $(*)$ & $0.2 \%$ \\
\hline Monaco & $(*)$ & $0.1 \%$ & Cote D'Ivoire & $(*)$ & $(*)$ \\
\hline Colombia & $(*)$ & $0.1 \%$ & New Zealand & $(*)$ & $0.2 \%$ \\
\hline Panama & $(*)$ & $0.5 \%$ & Colombia & $(*)$ & $0.1 \%$ \\
\hline Croatia & $(*)$ & $0.1 \%$ & Greece & $(*)$ & $0.1 \%$ \\
\hline Estonia & $(*)$ & $0.1 \%$ & Czech Republic & $(*)$ & $0.5 \%$ \\
\hline Chile & $(*)$ & $(*)$ & Slovenia & $(*)$ & $0.1 \%$ \\
\hline Belize & $(*)$ & $0.3 \%$ & Philippines & $(*)$ & $(*)$ \\
\hline Ukraine & $(*)$ & $(*)$ & Kuwait & $(*)$ & $0.1 \%$ \\
\hline Seychelles & $(*)$ & $0.1 \%$ & Iceland & $(*)$ & $0.2 \%$ \\
\hline New Zealand & $(*)$ & $0.1 \%$ & Slovakia & $(*)$ & $0.4 \%$ \\
\hline Trinidad And Tobago & $(*)$ & $(*)$ & Congo, Republic Of & $(*)$ & $(*)$ \\
\hline Liberia & $(*)$ & $0.1 \%$ & Brunei Darussalam & $(*)$ & $(*)$ \\
\hline Gibraltar & $(*)$ & $0.2 \%$ & Belize & $(*)$ & $0.1 \%$ \\
\hline Uzbekistan & $(*)$ & $(*)$ & Latvia & $(*)$ & $0.2 \%$ \\
\hline $\begin{array}{l}\text { Iran (Islamic Republic } \\
\text { Of) }\end{array}$ & $(*)$ & $(*)$ & $\begin{array}{l}\text { Saint Vincent And The } \\
\text { Grenadines }\end{array}$ & $(*)$ & $(*)$ \\
\hline Moldova, Republic Of & $(*)$ & $(*)$ & Seychelles & $(*)$ & $0.1 \%$ \\
\hline Bulgaria & $(*)$ & $0.1 \%$ & Bulgaria & $(*)$ & $0.1 \%$ \\
\hline Namibia & $(*)$ & $(*)$ & Bosnia And Herzegowina & $(*)$ & $(*)$ \\
\hline Kazakhstan & $(*)$ & $(*)$ & Romania & $(*)$ & $0.2 \%$ \\
\hline Bahrain & $(*)$ & $(*)$ & Belarus & $(*)$ & $0.1 \%$ \\
\hline Romania & $(*)$ & $0.1 \%$ & Algeria & $(*)$ & $(*)$ \\
\hline Vanuatu & $(*)$ & $(*)$ & Mauritius & $(*)$ & $0.1 \%$ \\
\hline \multirow[t]{20}{*}{ Thailand } & $(*)$ & $(*)$ & Morocco & $(*)$ & $(*)$ \\
\hline & & & Angola & $(*)$ & $(*)$ \\
\hline & & & Kazakhstan & $(*)$ & $(*)$ \\
\hline & & & Viet Nam & $(*)$ & $(*)$ \\
\hline & & & Oman & $(*)$ & $(*)$ \\
\hline & & & Indonesia & $(*)$ & $(*)$ \\
\hline & & & Chile & $(*)$ & $(*)$ \\
\hline & & & Iran (Islamic Republic Of) & $(*)$ & $(*)$ \\
\hline & & & Estonia & $(*)$ & $0.1 \%$ \\
\hline & & & Sri Lanka & $(*)$ & $(*)$ \\
\hline & & & Bahrain & $(*)$ & $(*)$ \\
\hline & & & San Marino & $(*)$ & $(*)$ \\
\hline & & & Dominica & $(*)$ & $(*)$ \\
\hline & & & Saint Kitts And Nevis & $(*)$ & $(*)$ \\
\hline & & & Moldova, Republic Of & $(*)$ & $(*)$ \\
\hline & & & Vanuatu & $(*)$ & $(*)$ \\
\hline & & & Marshall Islands & $(*)$ & $(*)$ \\
\hline & & & Andorra & $(*)$ & $(*)$ \\
\hline & & & Costa Rica & $(*)$ & $(*)$ \\
\hline & & & Kenya & $(*)$ & $(*)$ \\
\hline
\end{tabular}

$\left.{ }^{*}\right)$ greater than zero but less than $0.05 \%$. 